\title{
Can Attenuated Leishmania Induce Equally Effective Protection as Virulent Strains in Visceral Leishmaniasis?
}

\author{
Joana Cunha, Eugenia Carrillo, Javier Moreno and \\ Anabela Cordeiro-da-Silva
}

Additional information is available at the end of the chapter

http://dx.doi.org/10.5772/57214

\section{Introduction}

The principle of antimicrobial vaccines is to increase immunity against a specific infectious agent so when the individual is challenged by that agent the appropriate immune response is mounted rapidly and efficiently. Vaccines for infectious agents have historically developed from whole live or dead microorganisms to more defined native or recombinant pure fractions, following antigen-coding DNA and the latest approaches of antigen-pulsed dendritic cells. Although bacterial and viral infections have a quite long list of effective vaccines, parasitic infections - from worms to protozoa - have been a hard challenge for researchers to be able to develop proper vaccines. Currently, the most advanced anti-parasitic vaccine is the RTS,S/ AS01 for malaria with a protection that covers 30-40\% [1]. Despite several attempts during seven decades of research with some promising approaches, so far there is no vaccine available for human leishmaniasis and the options available for veterinary use have zone-restricted market authorization, being inaccessible to many endemic countries.

Traditionally, live vaccines incorporate attenuated strains that after entering the host cause a non-pathological short-lived infection, being rapidly controlled by the innate and adaptive immune systems. In few words, the microorganism is taken up and processed by antigen presenting cells (APCs) that efficiently expose the microbial antigens via MHC class I or MHC class II molecules, activating the cognate $\mathrm{T}$ cell receptors (TCRs) on the surface of $\mathrm{CD}^{+}$or $\mathrm{CD}^{+} \mathrm{T}$ cells, respectively. From here, the effector cellular and humoral machinery develop a specific response aiming to eliminate the aggressor. When a sterile cure (i.e. complete elimination of the microorganisms) is achieved, a contraction in all the effectors takes place, though specific central memory $\mathrm{T}$ cells and antibodies endure [2], being ready to initiate a stronger response upon a second encounter with a similar microorganism. However, the abidance time 
of memory is highly dependent on the strength of the primary response. Studies using mice models have shown that small numbers of parasites restricted to the inoculation site, without causing clinical manifestations, are essential for protection from a virulent challenge [3], indicating that antigen persistence is of major importance in a vaccination protocol for leishmaniasis. In fact, this is the concept behind the leishmanization strategy applied in humans.

In this chapter we address some general aspects of the epidemiology of human and canine leishmaniasis to introduce the needs for a vaccine and the desirable immune response to be generated upon vaccination. We present the animal models most commonly used in leishmaniasis vaccine research, the road so far travelled by the scientific community attempting to discover the vaccine for leishmaniasis and its current status. Finally, we show our experimental study in BALB/c mice about the influence of a primary infection of Leishmania infantum on the outcome of a de novo infection with a homologous or heterologous strain with distinct infectivity and immunomodulation.

\subsection{Human leishmaniasis}

Leishmaniasis is endemic in 98 countries and 3 territories ranging the Mediterranean Basin, the Middle East, the Indian sub-continent, and the tropical regions from America and Africa [4]. The last WHO report on the epidemiology of leishmaniasis estimates that every year 0.7 to 1.2 million new cases of cutaneous leishmaniasis (CL) are mounted and 0.2 to 0.4 million people develop visceral leishmaniasis (VL) which, in turn, is responsible for 20000 to 40000 deaths [4]. Nevertheless, in endemic countries most of the L. infantum- or L. donovani- infected people are asymptomatic carriers or self-healers $[5,6]$.

The relation of leishmaniasis with poverty catalogues it as a neglected tropical disease. In fact, 72 of the endemic countries are developing nations with a burden of $90 \%$ of the VL, CL and mucocutaneous leishmaniasis (MCL) [7]. In these regions, the majority of the population lives in rural areas, where higher densities of sand flies are found, and is malnourished, a condition that leads to immunosuppression. In addition, HIV concomitant infection is frequent, contributing to a severe state of immunodeficiency [8]. The close geographical overlap of Leishmania and HIV promote the concomitant infection of both pathogens. In fact, HIV infection increases in 100-2320 times the risk of developing VL in the endemic regions. HIV/Leishmania coinfections correspond to $2-9 \%$ of all the VL cases in endemic countries [9]. Furthermore, leishmaniasis is nowadays an important issue in developed countries due to coinfection cases with HIV where Leishmania arises as an opportunistic infectious agent, the third of the parasitic infections after Toxoplasma gondii and Cryptosporidium spp. [10]. Indeed, 90\% of the reported HIV/Leishmania cases are from Southern European countries, namely Spain, Portugal, Italy and France [8]. The routine use of highly active antiretroviral therapy (HAART) by the end of 1990's produced a clear decrease of HIV/Leishmania coinfection cases in southern Europe, but it is now a growing concern in those major foci of leishmaniasis in developing countries like Ethiopia, where the incidence of HIV is still high [9]. In addition, following the climatic changes that currently allow the presence of the vector in higher latitudes and the constant circulation 
of people and animals crossing frontiers and oceans, nowadays leishmaniasis cannot anymore be considered restricted to the endemic countries but is otherwise spread in the world.

The progression of a Leishmania infection to clinical disease comprises multifactorial phenomena, including the tropism of the species and strains, the genetic background of the host and the efficiency of the immune response developed against the parasite [11]. Studies using mice models have helped the scientific community to better understand the host-parasite relationship in leishmaniasis. Interleukin (IL) - 12 is considered a key cytokine in the early development of the effective immune response due to its requirement for the activation of natural killer cells and T lymphocytes [12]. Activation of these cells leads to the secretion of interferon- $\gamma(\operatorname{IFN} \gamma)$, another commander cytokine.

Both in mice as in humans, macrophages are classically activated by IFN $\gamma$. This leads to the transcription of inducible nitric oxide synthase (iNOS) and phagocyte NADPH oxidase (phox) that produce nitric oxide (NO) and reactive oxygen species, respectively, specimens generally considered indispensable for macrophage-direct killing of Leishmania [13]. Macrophages activated by IL-12-driven IFN $\gamma$ secretion by Th1 lymphocytes - named M1 macrophages - also produce TNF $\alpha$, IL-1 $\beta$ and IL-6, pro-inflammatory cytokines that favor the protective response against Leishmania infection. These macrophages are, then, both effectors and inducers of the Th1 polarized immune response [14]. Nevertheless, the strong Th1 pro-inflammatory response must be balanced with the secretion of IL-10 and transforming growth factor- $\beta$ (TGF $\beta$ ) to avoid immunopathology through excessive tissue damage [15].

Effector $\mathrm{CD}^{+}$and $\mathrm{CD}^{+} \mathrm{T}$ cells that were activated by the recognition of Leishmania antigens on the cognate TCR and expanded to respond to infection will face a massive contraction on their numbers of about $90 \%$ after the elimination of the parasite, leaving a subset of experienced cells that constitute the memory pool. Memory cells are long-lived cells that rapidly expand in response to a secondary challenge with the priming antigen [16]. They form a heterogeneous pool with distinct abilities in proliferation, migration and cytokine production, which allow their classification in central memory (TCM) or effector memory T cells (TEM).

Memory cells were demonstrated to have great importance in the control of leishmaniasis, with distinct roles described for TCM and TEM cells. Zaph et al. have shown that in mice both $\mathrm{TCM}$ and TEM CD4 ${ }^{+}$cells require parasite presence to be developed, though maintenance of TCM is independent of antigen persistence [2]. This achievement, however, seems highly dependent on the initial overall $\mathrm{T}$ cell response, since in some immunization experiments that used low dose of parasites protection was lost after the elimination of the parasites, possibly due to insufficient expansion of the TCM pool [3]. Adoptive transfer of TCM from L. majorinfected mice to naïve animals conferred protection upon a challenge. When facing the antigen, TCM expanded in the lymph nodes, acquired effector functions, including CD62L downregulation which allowed their migration to the infection site and effective protection [2]. In accordance, analysis of $\mathrm{CD}^{+}$memory $\mathrm{T}$ cells from patients with CL stimulated ex-vivo with soluble Leishmania antigen (SLA) revealed the high proliferative ability and IL-2 production of TCM and high percentage of IFN $\gamma$-secreting TEM [17]. 
Nevertheless, concomitant immunity, i.e. efficient protection upon a challenge due to the longterm and simultaneous persistence of the pathogen, seems to be a hallmark in leishmaniasis [18].

\subsection{Canine leishmaniasis}

Dogs are primary reservoir hosts of zoonotic visceral leishmaniasis (ZVL) caused by Leishmania infantum and play a key role in the long-term maintenance of the parasite in the endemic areas of Mediterranean countries, the Middle East, Asia and Latin America. Epidemiological surveys estimate that, for example in western Mediterranean countries, seroprevalence ranges from 5 to $37 \%$, varying from region to region depending on ecological aspects. Nevertheless, surveys based on PCR diagnosis demonstrated high infection rates in endemic areas, for example $80 \%$ in Marseille, France [19], and 67\% in Majorca, Spain [20]. Longitudinal studies in Italy have also shown high incidences (40-92\%) during the season of transmission [21]. Importantly, not all infected dogs develop canine leishmaniasis; more than $50 \%$ of infected dogs remain asymptomatic after infection, though it has been shown that these asymptomatic carriers are also infective to sandflies [22].

The high prevalence of infected dogs in endemic areas, their common presence in the domestic surroundings where ZVL transmission occurs, and the high infectiousness of both symptomatic and asymptomatic animals makes that Leishmania-infected dogs represent not only a serious veterinary but also an important public health problem. Infected dogs have been associated with the emergence of new foci of ZVL, like those in the North of Argentina, where the appearance of human cases is preceded by those of canine leishmaniasis [23], and also with the spread of VL observed in large Brazilian cities [24] and the northward spread of the disease reported in Italy [25]. Therefore, the control of parasite-infected dogs is of prime urgency to reduce the number of cases of human VL by decreasing prevalence in dogs [26].

The outcome of Leishmania infection in dogs is variable and depends on the persistence and multiplication of the parasite and the immune response of the animal. Not all the infected dogs will develop clinical disease, part of them can control the expansion of the parasite and spontaneously cure the infection; in others, the infection is subclinical for an undefined time (years or even the whole life) during which the animal remains asymptomatic. Few than $50 \%$ of infected animals do not have (or have lost) the capacity to control the parasite, in these cases being distributed extensively throughout the organism: spleen, liver, lymph nodes, bone marrow, kidney, skin, etc., (as opposed to what occurs in humans, where the parasite is normally limited to bone marrow, spleen and liver) [26]. In these dogs the disease progresses, the parasite burden and the Leishmania-specific antibody levels increase, and after two to four months of incubation the symptoms of canine leishmaniasis appear [27].

The natural history of canine leishmaniasis mostly depends on the efficacy of the dog's immune response to L. infantum infection which determines the development of resistance or susceptibility to the disease. In general, resistance is associated with low levels of specific antibodies and presence of a predominant Th1 cell-mediated response against the parasite, with the production of IFN $\gamma$ that is able to stimulate, in collaboration with TNF $\alpha$, the leishmanicidal activity of macrophages mediated by the induction of iNOS. Absence of symptoms is related with high levels of IFN $\gamma$ expression in the peripheral blood as detected by quanti- 
tative real-time PCR [28]. When dogs develop such parasite-specific cell-mediated immunity, they are able to control parasite dissemination and present an overall low tissue parasitism. This status of resistance is reflected in the development of a positive leishmanin skin test or/and an in vitro lymphoproliferative response after stimulation of peripheral blood mononuclear cells (PBMCs) with leishmanial antigens. In these animals, it has been observed that in vitro stimulation of PBMCs with L. infantum SLA induces the expression of IL-2, IFN $\gamma$, TNF $\alpha$, IL-4 and IL-10, confirming the existence of both Leishmania-specific Th1 and Th2 clones [29]. Also, quantification of the cytokine expression by real-time PCR allowed to establish that PBMCs from resistant dogs expressed high levels of IFN $\gamma$ and TNF $\alpha$ after in vitro stimulation with purified parasite antigens [30,31]. Therefore, the evaluation of IFN $\gamma$ expression level from PBMCs constitutes a good approach to evaluate the in vitro immunogenicity of leishmanial molecules to identify vaccine candidates able to induce the protective cellular immune response to canine leishmaniasis [30, 32].

Different attempts have been made to confirm a correlation between the classes and subclasses of immunoglobulins and the type of response against Leishmania infection in dogs. Early studies associated the appearance of specific IgG2 antibodies against Leishmania with the asymptomatic state of the dogs, and the preponderance of IgG1 with progression of the disease [33]. However, other studies have failed to show this [34, 35]. Recent reports have proposed the analysis of IgG, IgG1 and IgG2 isotypes as immune biomarkers for the assessment of the immunogenicity of vaccines against canine leishmaniasis. Since IgG1 and IgG2 responses are largely $\mathrm{T}$ cell dependent, the evaluation of the specific isotypes has been considered an important aspect to evaluate the overall immunity induced by a specific vaccine. It has been seen that IgG2 induced by vaccination with $L$. infantum excreted/secreted proteins ( $L i \mathrm{ESP}$ ) had a potent inhibitory effect on the in vitro growth of both amastigotes and promastigotes and that the pre-treatment of amastigotes with this serum reduced significantly their in vitro infectivity in canine macrophages [36].

It is important to remark that the lack of Leishmania-specific cell mediated immunity constitutes a key aspect in the pathogenesis of canine leishmaniasis and also in the recovery of the animal after treatment. It has been confirmed that successful chemotherapy of the animals correlates not only with the disappearance of external signs of leishmaniasis but also with a significant increment in the percentage of $\mathrm{CD}^{+} \mathrm{T}$ cells and the appearance of a parasite-specific proliferative response of PBMCs [37].

\section{Vaccine research for leishmaniasis}

The ideal vaccine for leishmaniasis should be safe, effective, long lasting, transversal to all infective Leishmania species and affordable, to be available to the populations most in need.

\subsection{Animal models for vaccine research for leishmaniasis}

Much of the knowledge generated from leishmaniasis research come from experimental infections in animal models. Differently from human population and natural infections, the 
most common models of disease employed in leishmaniasis research are based on infection of inbred mice with cloned lines of parasites. These experimental settings reduce the variety of factors that play a role on the disease manifestation, such as host's genetic background and immune competence, concomitant infections with other microorganisms, autoimmune or inflammatory diseases or drug treatments that may affect the fitness of the immune system, diversity of parasite's strains and species, site of infection and inoculum dose, infecting sand fly's species, etc. However, in comparison to the natural transmission and disease, the same limitations are also the major advantages, as in laboratorial settings researchers control all those variables and are able to focus on their specific target to unravel the molecular and immunological mechanisms behind leishmaniasis.

Many models of leishmaniasis have been tested, although none is able to mimic the exact pathology of cutaneous and, principally, visceral human diseases, or to develop the same immune responses. Despite valuable information has come from animal models, careful generalizations must be done when transposing it to the human disease.

The animal species applied on studies of human CL is almost exclusively the mouse (Mus musculus). Inbred strains are experimentally infected by subcutaneous or intradermal route with millions of promastigotes cultivated in vitro or axenic or tissue-derived amastigotes. The mice's genetic background has a major impact on the severity of the disease. For instance, when infected with a high dose BALB/c strain develops extensive skin lesions that spread away from the inoculation site leading to death of the animal, while C57BL/6 and CBA/N are able to control the infection and skin ulcers self-heal with time [38].

Considering animal models for VL, golden hamsters (Mesocricetus auratus) are among the best mimicking model of the human disease. Despite the artificial route (intracardiac or intravenous) and the high amount of parasites usually inoculated, L. infantum- or L. donovani-infected hamsters show heterogeneous phenotypes of infection, with animals that are asymptomatic, oligosymptomatic or polysymptomatic, in quite a good correlation with human and also canine epidemiology in endemic areas. Symptomatology comprise weight loss, uncontrollable increase in the splenic, hepatic and bone marrow parasite loads, hepatosplenomegaly, pancytopenia, hypergammaglobulinemia and ultimately death (Carrillo et al., submitted, 2013 and [39]). Due to the lack of specific reagents needed to study the immunological mechanisms associated with Leishmania infection, the hamster model has been put apart and neglected over the mice models. Visceral leishmaniasis in mouse do not fully resemble the human nor canine disease, but the availability of numerous strains genetically modified and an endless offer of anti-mouse antibodies make the mouse the most preferred model to understand the hostparasite interactions and the immunological aspects of visceral leishmaniasis. However, in the scope of vaccine development and drug screening, where more than the mechanism behind the most important read-out is efficacy (i.e. parasite loads and pathology), golden hamsters are the most appropriate rodent model for the human disease.

The use of dogs (Canis lupus familiaris) as model of leishmaniasis is an advantage in the way that dogs are themselves natural hosts. Some breeds, like German Shepard, Boxer and Doberman, seem to be more susceptible to natural Leishmania infection [40]. However, the most common breed used in laboratorial studies is the Beagle. In addition, many research studies are done with field animals. They can be artificially infected or put in natural contact with sand flies in 
endemic areas to test the efficacy of vaccines or anti-Leishmania drugs for veterinary practice or be used in the scope of model for human VL. Despite the existence of some dog-specific tools that would allow the study of the immune response, working with dogs is not as easy as handling mice, due to their size, the unpredictability of the infection rates, the cost of the experiments and the emotional connection that naturally exist between humans and dogs.

Non-human primates are usually confined to pre-clinical trials in humans. Some models based on artificial inoculation of rhesus macaques (Macaca mulata) [41], African vervet monkeys (Chlorocebus spp.) [42] or langur monkeys (Presbytis entellus) [43, 44] have been tested for Leishmania vaccines. Due to the close phylogenetic relation with humans and considerably good mimicking of pathology and immune responses generated upon infection (depending on the parasite and animal species), these models are attractive for vaccine research. But the difficulty on the handling, the very expensive costs and the impossibility of exposing the animals to a natural challenge are drawbacks on the use of non-human primates for Leishmania vaccine research.

\subsection{Leishmanization}

Until date, the only successful, long-lasting strategy for human immunization against leishmaniasis is the leishmanization process. It consists on the inoculation of live virulent parasites in a hidden area of the skin of healthy people with the purpose of development of immunity for protection when the individuals are challenged by a natural infection. Leishmanization showed $100 \%$ protection when used as prophylaxis for cutaneous leishmaniasis (CL) throughout the ex-Soviet Union, Asia, and the Middle East [45]. Due to risk of complications in healthy people and difficult standardization of the live L. major inoculum, this procedure was mostly abandoned. However, this is still a current practice in Uzbekistan [45] and a few years ago it was reported to be applied in the evaluation of the efficacy of new vaccines [46].

A "natural" form of leishmanization may be the reason why in Sri Lanka so many cases of CL by $L$. donovani are reported while VL is rare [47]. McCall et al. have recently reproduced this scenario in the BALB/c model, immunizing the mice subcutaneously with a dermotropic $L$. donovani strain from Sri Lanka followed by intravenous challenge with a viscerotropic autochthonous strain, and indeed, partial protection was obtained in the liver of the infected mice [48]. The authors attributed the ability of the cutaneous strain to protect against the challenge with the visceral strain to a probable great similarity between the two L. donovani strains; this hypothesis may justify the opposing phenotype observed by others [49]. Also, an epidemiological study in Sudan indicated that only individuals previously negative for leishmanin (Montenegro skin test) developed VL, thus, though without scientific evidences, leishmanin-positive individuals that were possibly formerly infected with L. major were protected against the visceral disease [50].

\subsection{First generation vaccines}

First generation vaccines comprise whole killed parasites and live attenuated parasites. They were primarily developed to overcome one of the major concerns related to leishmanization: 
the risk of disease development in immunocompetent persons and the total improperness for immunosuppressed patients for this same reason.

\subsubsection{Killed parasites}

With more or less success, some examples of killed vaccines include L. braziliensis crude antigens tested in dogs [51] and trivalent (L. braziliensis + L. guayanensis + L. amazonensis) phenolkilled whole Leishmania promastigotes with bacille Calmette-Guérin (BCG) as adjuvant in Ecuadorian children [52]. According to a meta-analysis conducted in 2009 by Noazin et.al. to evaluate the efficacy of the clinical trials performed with whole killed parasites in endemic areas since 1970's, with the exception of this latter in Ecuador, none of the other eight clinical trials considered (based on autoclaved L. major (ALM) with BCG tested against CL in the Old World and L. amazonensis or multivalent preparations inactivated with merthiolate used against CL in the New World) showed significant protection against natural infection [53]. A new option was tested recently: a killed but metabolically active (KBMA) L. infantum. This vaccine showed partial protection in spleen and liver of BALB/c mice 2 and 8 weeks after challenge triggering a mixed Th1/Th2 response but the authors claim that improved results could be obtained by adding TLR agonists and Th1 adjuvants [54].

\subsubsection{Live attenuated parasites}

For the live attenuated parasites many are the works reported whether using physical, chemical or genetic manipulation for reducing the virulence of the strains, or even naturally attenuated strains, like the non-pathogenic L. tarentolae [55]. Some of the most successful vaccine candidates for VL based on genetically altered live parasites were $L$. donovani biopterin transporter gene knockout $(\mathrm{KO})\left(B T 1^{-/}\right)[56]$, L. donovani replication deficient centrin gene $\mathrm{KO}$ $\left(\mathrm{Cen}^{--}\right)$[57], L. donovani cytochrome c oxidase complex component p27 gene $\mathrm{KO}\left(\mathrm{Ldp} 27^{-/-}\right)$[58], L. infantum silent information regulatory 2 single $\mathrm{KO}\left(S I R 2^{+-}\right)$[59] and L. tarentolae expressing L. donovani A2 antigen [60]. Despite showing hopeful efficiency in murine models, the promising candidates that were tested in human and canine diseases failed to protect (reviewed in [61]).

\subsection{Second generation vaccines}

A different approach relies on recombinant proteins, polyproteins, DNA vaccines, liposomal formulations and dendritic cell vaccine delivery systems [45]; these constitute the second generation vaccines.

\subsubsection{Purified or recombinant Leishmania antigens and engineered polyproteins}

The Leishmania antigen that has been more extensively studied in the scope of a vaccine is the gp63 glycoprotein that is expressed on the surface of both the amastigotes and the promastigotes forms. The recombinant and the native proteins have been inoculated in several strains of mice as models of CL, generally showing a protective phenotype (see [62] for details). Also, an early study using monkeys revealed a partial protection against CL by L. major [63]. This 
gp63 is one of the few recombinant antigens studied in the scope of VL; Bhowmick et al. showed that gp63 encapsulated in cationic liposomes induced more than $80 \%$ reduction of the parasite loads in spleen and liver of BALB/C mice infected with L. donovani [64]. In this group of recombinant antigens, some others of the most successful candidates against VL were the amastigote-specific protein rA2, rHASPB1 (hydrophilic acylated surface protein B1), KMP-11 (kinetoplastid membrane protein-11) and rORFF (open reading frame fragment). LiESA ( $L$. infantum promastigotes' excreted/secreted antigens), FML (fucose-mannose ligand) and GRP78 (glucose-regulated protein 78) are the few purified antigens tested in vaccines for VL and all of them revealed at least certain degree of protection (see the reviews from Evans and Kedzierski [45] and Nagill and Kaur [62] for details and references). For CL, other antigens tested by several groups, though with conflicting results, are rLACK (Leishmania homologue of receptor for activated C kinase) [65-67] and PSA-2 (promastigote surface antigen 2) [68, 69].

Concerning the recombinant polyproteins, rLeish-111f (or LEISH-F1, composed of three molecules fused in tandem: the L. major homologue of eukaryotic thiol-specific antioxidant (TSA), the L. major stress-inducible protein 1 (LmSTI1) and the L. braziliensis elongation and initiation factor (LeIF)) and its non His-tag form rLeish-110f are undoubtedly the best studied and the most promising candidates for a vaccine against leishmaniasis. After having proved to protect mice with CL [70] and VL [71], rLeish-111f with MPL-SE adjuvant has also demonstrated to be safe and well tolerated in humans [72] as well as immunogenic in healthy subjects of endemic areas with or without previous contact to L. donovani [73]. Clinical trials in dogs have resulted in disparate conclusions about the efficacy of the vaccine in the prophylaxis of ZVL $[74,75]$, though survival of infected dogs was increased after vaccination and treatment with glucantime [76]. rLeish-110f with MPL-SE was shown to be immunogenic and protective in BALB/c mice after L. major and L. infantum challenges [77] (see [78] for complete information about the clinical trials run with rLeish-f111 and rLeish-f110).

Another polyprotein named Protein $Q$, composed of the fusion of four fragments of the acidic ribosomal protein Lip2a, Lip2b, P0 and histone 2A, has shown $90 \%$ protection as measured by parasite clearance in vaccinated dogs using BCG as adjuvant [79]. After testing other adjuvants in mice, $99 \%$ protection was achieved against $L$. infantum when administering Protein $Q$ with CpG-ODN [80].

\subsubsection{DNA vaccines}

DNA vaccines are able to activate both $\mathrm{CD}^{+}$and $\mathrm{CD}^{+}$T cells through the engagement of $\mathrm{MHC}$ class II and MHC class I, respectively [38]. In addition, co-administration of cytokines and CpG oligonucleotides allows the modulation of the cellular immune response [81]. Besides being relatively easy to prepare and stable, another unique advantage is the appropriate folding of the intracellularly synthetized peptide on its native structure [38].

The first DNA vaccines to be studied were the classical candidates that have been tested as proteins. As single plasmids or in multicomponent DNA vaccines, there are successful examples that have shown to protect from some Leishmania species but not others, or were effective in some animal models but not others (see [62] for an extensive description of DNA vaccines). Among the most investigated are gp63 for CL in mice, LACK and KMP-11 for both 
CL and VL tested in mice, hamsters and dogs. Some reports have shown the use of the strategy of heterologous prime-boost using LACK DNA followed by administration of rLACK protein with positive results [82-86].

\subsubsection{Dendritic cell vaccine and liposomal formulations delivery systems}

The unique capacity of DCs in amplifying the innate defense mechanisms and providing the link between these and the acquired immune responses makes them ideal candidates for antiLeishmania vaccines [87]. In the recent years, DCs pulsed with gp63 or gp63-derived peptides [88, 89], histone H1 [90] or a mixture of histones [91] delivered to mice challenged with $L$. major or DCs pulsed with KMP-11(12-31aa) peptide + CpG ODN [92] against L. infantum have shown to decrease lesion size and parasite loads through the production of antigen-specific IFN $\gamma$.

On another approach, the concept behind the use of liposomes to deliver Leishmania antigens is that they can modulate antigen presentation, enhancing antigen-specific T cell proliferation and humoral responses. Conventional liposomes are presented by MHC class II molecules, whereas the presentation via MHC class I requires $\mathrm{pH}$-sensitive liposomes [93]. The encapsulation of rgp63 or rLmSTI1 in liposomes has proven to develop a Th1 response that protected BALB/c mice from L. major [94, 95] or L. donovani infection [64]. A different strategy using polar phospholipids from Escherichia coli to encapsulate L. donovani SLA protected hamsters from $L$. donovani infection by the production of $\mathrm{CD}^{+}$and $\mathrm{CD}^{+} \mathrm{T}$ cell-specific responses [96]. Importantly, the route of administration of the liposomes may have a crucial role on the generation of the protective response. For example, BALB/c mice that were immunized by intravenous or intraperitoneal routes with liposomal $L$. donovani membrane antigens were protected from a L. donovani challenge, whereas the intramuscular or subcutaneous immunizations failed to protect [97].

\subsection{Adjuvants}

Adjuvants are synthetic or natural highly immunogenic components that are combined with the specific immunizing antigen with the purpose of efficiently stimulate the immune cells to mount a strong response against that antigen. Adjuvants are usually categorized in two classes. Immunostimulatory or non-particulate adjuvants are agonists of the pathogen-recognition receptors (PRRs) that localize at the surface or inside intracellular vesicles of innate immune cells [93]. These are activated by the binding of the cognate pathogen associated molecular patterns (PAMPs) (or their agonists) and signal a complex cascade of events that triggers the secretion of cytokines, chemokines and type I interferons [98]. The other class comprise the particulate adjuvants which are mineral-, lipid- or polymer-based delivery systems that, along with being transporters of the Leishmania antigen, are themselves immunostimulators due to their size, charge and composition; their properties can even be further improved by the decoration with other PAMP-like adjuvants [93].

In a vaccine for leishmaniasis, it is expected that adjuvants modulate the immune system towards a Th1 response, with high amounts of secreted IL-12 and IFN $\gamma$. Indeed, recombinant 
IL-12 has been successfully tested in animal models as a potent adjuvant. However, stimulation with IL-12 was unable to induce a strong memory response to the immunizing antigen in BALB/c mice [99]. Nevertheless, when administered as IL-12 DNA it induced long-lasting protection against L. major [100].

$\mathrm{MPL}^{\circledR}$ is a purified derivative of the monophosphoryl lipid A hydrophobic moiety of Salmonella minnesota's lipopolysaccharide (LPS). As LPS, MPL ${ }^{\circledR}$ is a potent TLR4 activator, though without the pyrogenicity of the parent molecule [101]. To even increase its efficacy, MPL ${ }^{\circledR}$ has been formulated in an oil-in-water stable emulsion in squalene (MPL-SE) which rendered high levels of IFN $\gamma$ and low amounts of IL-4 and IL-10 [102]. A similar derivative, GLA-SE (glucopyranosyl lipid adjuvant) has been chemically synthetized in order to obtain a pure molecule, free of biological components, but still maintaining the same multifunctional immunomodulatory activity as the naturally-derived MPL ${ }^{\circledR}$ [103]. Currently, MPL-SE and GLA-SE are undergoing clinical trials with the antigen LEISH-F3 for the first vaccine for human VL (see section 2.6.2).

Other TLR agonists are CpG-containing oligonucleotides (CpG ODNs) and imiquimod, which are ligands for the TLR9 and TLR7/8, respectively. CpG ODNs are strong immunostimulators by the upregulation on macrophages and DCs of CD40 and MHC class II costimulatory receptors [104] and the induction of IFN $\alpha, \operatorname{IFN} \beta$ and IFN $\gamma$, IL-12, IL-18 and TNF $\alpha$ secretion by lymphocytes [105]. In the same direction, imiquimod, a synthetic imidazoquinoline, is a Th1 activator. But noteworthy, imiquimod has itself anti-leishmanial activity through the activation of macrophages leading to the secretion of IL-12 and IFN $\gamma$ [106]. Also, signal transduction directed to NO production was detected on $L$. donovani-infected macrophages treated with imiquimod [107]. Indeed, a recent report showed the effective application of topic imiquimod on the cutaneous lesions of a child infected with L. infantum unresponsive to liposomal amphotericin B [108].

Bacillus Calmette-Guérin (BCG), besides being the most widely administered vaccine in the world, it is also commonly used as adjuvant in numerous vaccine candidates for infectious diseases. In anti-Leishmania treatment [109] and vaccine research it has been tested in murine [110-112], hamster [113], canine [114, 115] and non-human primate models [42] (just to mention the most recent works). Its mechanism of immunostimulation relies on the activation of TLR2, TLR 4 and TLR9 $[116,117]$ in addition to its anti-leishmanial properties revealed in early studies $[118,119]$.

Saponins are natural products from the Quillaja saponaria tree chemically modified in order to increase their adjuvant properties [120]. QuilA is the heterogeneous mixture of saponins obtained from the aqueous extract of the Quillaja bark. Due to its high toxicity, purification by HPLC and chemical modifications have originated several saponins which display different toxicity and immunogenicity [121]. Saponins are common adjuvants used in vaccines for Leishmania. Indeed, the three approved vaccines for ZVL include saponins in their formulation (see section 2.6.1).

Particulate adjuvants have many properties that can be designed to bias the immune system in the desirable way which make them very versatile adjuvants. They serve as carriers for 
antigens and non-particulate adjuvants, targeting both vaccine components to the same APC and controlling their release. They can be used to increase the stability of antigens, like proteins, peptides or oligonucleotides, to improve the solubility of hydrophobic compounds or to bypass gastric degradation [93].

Aluminum salts are common in human and veterinary vaccines, though they are not proper adjuvants per se to be used in vaccines for leishmaniasis because their immunostimulatory properties drive a Th2 response. However, they have been used as carriers for other adjuvants, like IL-12 [122] or BCG [111], in combination with ALM antigen. Lipid-based vesicles (liposomes and niosomes) have been tested to carry ALM antigen with or without BCG in C57BL/ 6 [123] and BALB/c mice [124]. Similarly, virosomes are spheres formed by a phospholipid bilayer but that also contain viral glycoproteins (hemagglutinin and neuraminidase from influenza virus) which confer structural stability and enhance the adjuvanticity of these particles [93].

Micelles and emulsions likewise fall in this category of particulate adjuvants as, for example, MPL $^{\circledR}$ and GLA formulated in stable emulsions (MPL-SE and GLA-SE). The oil-in-water emulsion formed with squalene (SE) is itself an adjuvant that has been included in the ongoing clinical trials run by IDRI (see section 2.6.2), though immunization with Leish-110f antigen plus SE led to the development of a Th2 response in BALB/c mice [77].

Finally, thought without great expression in Leishmania vaccine research, the most complex particulate adjuvants are the immune stimulating complexes. ISCOMATRIX ${ }^{\mathrm{TM}}$ are cage-like structures composed of cholesterol, lipids and QuilA bond together by hydrophobic interactions; they allow the inclusion of several antigens forming ISCOMATRIX ${ }^{\mathrm{TM}}$ vaccines [102]. Similar structures that include a hydrophobic antigen are called ISCOMs, while hydrophilic antigens must be held in cationic ISCOMs-like structures named PLUSCOMs [93]. The inclusion of QuilA in these systems allows the reduction of its amount and the bonding to cholesterol, therefore leaving no free QuilA to interact with cell membranes, which decrease its toxicity [93].

\subsection{Current status of vaccine research}

\subsubsection{Vaccines for zoonotic visceral leishmaniasis}

In canine vaccinology three authorized vaccine options are available.

Leishmune ${ }^{\circledR}$ was the first vaccine licensed for the prevention of ZVL but is authorized only in Brazil. It consists of L. donovani purified fucose-mannose ligand (FML antigen) in combination with a saponin adjuvant. Clinical trials have showed that Leishmune ${ }^{\circledR}$ reduces the risk of infection but also prevents disease progression in already infected dogs, though the manufacturer does not recommend the vaccine as immunotherapy. A transmission-blocking activity was also attributed to this vaccine, making it highly appealing for the control of the zoonosis [125]. After 5 years of spread use among veterinary clinics in all the Brazilian territory, the manufacturer reports an efficacy of $97.3 \%$ in 8393 vaccinated Leishmania-seronegative dogs exposed to the natural challenge [126]. Strong cellular response (determined as Leishmania- 
specific lymphoproliferation with high levels of IFN $\gamma$ in the absence of IL-10 and positive Montenegro skin reaction test) and favorable humoral response (with high titers of Leishmania-specific IgG2) are behind this protective response in vaccinated animals [126].

Some years later, Leish-Tec ${ }^{\circledR}$ was released, also only in Brazil. The recombinant A2 protein is the antigen that constitutes the vaccine along with saponin adjuvant. Protection was found to be related to high levels of anti-A2 IgG and IgG2, without the presence of IgG1, and high amounts of specific IFN $\gamma$ with low levels of IL-10 [127]. However, there is no updated information about the efficacy of the vaccine in the field.

Recently, a new vaccine, CaniLeish ${ }^{\circledR}$, the only authorized in Europe, has entered the market for the prophylaxis of ZVL. The manufacturer claims that vaccinated dogs have a 4 -fold reduced risk of developing the disease compared to non-vaccinated animals [128]. The use of L. infantum excreted/secreted proteins associated to QA-21 adjuvant (LiESP/QA-21) leads to the increase of IgG2 specific antibodies, stronger Leishmania-specific lymphoproliferation with an increased IFN $\gamma$-producing T cell population that is able to activate a significant leishmanicidal macrophage ability in vitro due to NO production [129].

\subsubsection{Ongoing clinical trials for a vaccine for $V L$}

On February 2012 the Infectious Disease Research Institute (IDRI) has launched a phase 1 clinical trial for the first vaccine against VL [130]. Thirty six healthy adult American volunteers were recruited to evaluate the safety, tolerability and immunogenicity of the LEISH-F3 recombinant antigen (composed of two fused proteins) with GLA-SE, MPL-SE or SE adjuvants [131]. About one year and a half later, this first clinical trial was completed and the vaccine was shown to be safe and to induce potent immune responses in healthy volunteers [132]. Later, IDRI partnered with the Indian pharmaceutical company Zydus Cadila to develop, register and market the three vaccine candidates to ensure that the possible future vaccine is affordable and accessible by the people that really need it. Also, in July 2013 this partnership has started phase 1 clinical trials in India to evaluate the effectiveness of the vaccine on individuals from endemic regions [132].

\section{Experimental data: Highly infective Leishmania infantum strain induces strong central and effector memory $\mathrm{CD}^{+}$and $\mathrm{CD}^{+}$immunity required for partial protection against re-infection}

\subsection{Aim of the study}

It is well accepted that the broad clinical manifestations described in leishmaniasis are associated with the different cytokine milieu developed in response to the infection, which is highly dependent on the parasite itself. Accordingly, a diversity of immune responses have been described for L. major substrains [133] and L. infantum strains from the MON-1 zymodeme [134]. These immune responses may have a pivotal importance if the host faces a de novo Leishmania infection. In fact, data from endemic countries put on evidence the reality of 
resistance to re-infection in VL. In the one hand, it is evident the predominance of L. infantum infections in children compared to adults [6], which may result from acquired resistance to re-infection in adulthood, and, on the other hand, there are the examples of fully recovered patients that showed resistance to re-infection by the same Leishmania species [61].

Some studies on re-infection have been performed in mice as model for visceral leishmaniasis. Streit et al. described a partial level of protection against $L$. chagasi when mice were first infected with a high-dose inoculum since it was able to stimulate the immune system towards a Th1 response for counteracting a subsequent infection. On the contrary, an infection with a low dose suppressed IFN $\gamma$ production and elicited high levels of TGF $\beta$. Also, protective immunity was not achieved if an attenuated dhfr-ts knockout strain was used instead for immunization [49]. However, Oliveira et al. published opposing results as when they infected mice with a low dose of $L$. chagasi a protective immune response was generated, while a high dose contributed to the development of visceral disease [135].

To our knowledge, there is no previous literature about the concomitant immunity developed with live virulent $L$. infantum infection followed by homologous or heterologous re-infection. Since the severity of the infection and the progression of visceral leishmaniasis are strongly determined by the elicited immune response, in this work we analyzed the ability of two $L$. infantum virulent strains, which have presented different infectivity and immunomodulation, in the generation of an effective adaptive immunity in the context of experimental chronic infection and in the induction of a recall response after re-infection in BALB/c mouse model.

\subsection{Development of protection needs highly infective Leishmania}

Many efforts have been made to understand how Leishmania-specific immunity is generated and maintained over time. Nowadays, it is of scientific consensus that early activation of the innate immune system is essential for the production of a reliable adaptive response that leans on $\mathrm{CD}^{+}$and $\mathrm{CD} 8^{+}$specific cellular immunity.

To understand the strain-specific immunomodulation mechanisms that lead to protection to re-infection we used two strains of L. infantum, one dermotropic (HL) and the other viscerotropic (ST), which presented differential onset and progression of VL in mice. As previously shown [136], HL was able to colonize the spleen, liver and bone marrow in higher extent than ST parasites 6 weeks after infection (Figure 1, Infection bars). We hypothesized that these differences in infectivity could lead to distinct levels of protection. Thus, we re-infected the mice with homologous or heterologous strains.

In our model, mice that were previously imprinted with HL strain and then challenged with the same highly infective strain (Figure 1, Re-inf HL bars) were able to sustain the splenic parasite load and to decrease in about 1 logarithm the number of parasites colonizing the liver and bone marrow. On the contrary, HL re-infection after ST imprinting led to a significant increase of about 1000 times in all the target tissues. Concomitant immunity was more pronounced when the animals were infected with the highly infective HL strain and then challenged with ST due to its lower infectivity (Figure 1, Re-inf ST bars). As such, the infections 
in the spleen and liver of HL imprinted mice suffered a significant reduction of $~ 1000$-fold in the parasite loads to levels close to the quantification limit, and in the bone marrow parasitic presence was detected but not quantifiable. Accordingly, ST imprinting and consecutive challenge resulted in a 10 -fold increase in the splenic and hepatic parasite burden compared to the primary infection numbers, though no changes were noticed in the parasite load of the bone marrow.

A

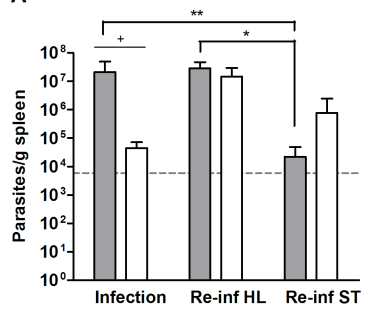

B

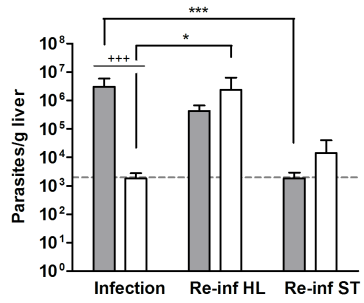

C

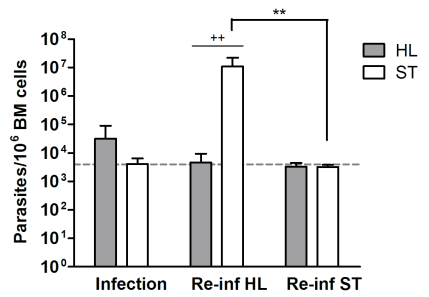

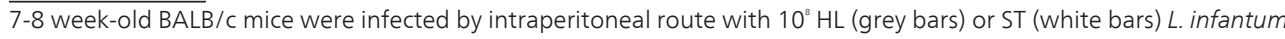
strains cultivated for 4 days in Novy-MacNeal-Nicolle (NNN) medium at $26^{\circ} \mathrm{C}$. After 6 weeks of infection mice were anesthetized with isoflurane and sacrificed by cervical dislocation (Infection bars). In the re-infection experiments, animals were infected for 6 weeks with HL or ST strains as before and challenged intraperitoneally with $10^{8}$ promastigotes of the same or the other strain; 6 weeks after challenge they were sacrificed (Re-inf HL and Re-inf ST bars). (A) Spleen, (B) liver and (C) femoral bone marrow were recovered for quantification of the parasite load by real time PCR [136]. Bars represent means \pm SD of 5 to 9 animals of one experiment representative of two independent. Statistically significant differences between $\mathrm{HL}$ and ST infections were calculated with Mann-Whitney test and are signed with * Kruskall-Wallis test followed by Dunn's multiple comparison test were used to calculate differences before and after challenge and are depicted with *. Statistical analysis was done in GraphPad Prism 5 (GraphPad Software). Dashed line indicates the limit of detection for quantification for each tissue.

Figure 1. Parasite load after infection and challenge with L. infantum strains presenting different infectivities

Based on the data exposed above, in terms of parasitological analysis we established that the onset of pathology (set as hepatosplenomegaly (data not shown; see [136]) and high parasite loads) by an infective L. infantum strain confers a degree of protection over a re-infection episode which correlates with the infectivity of both the imprinting and the challenging strains that are inoculated in the host. Similar findings were reported previously, when a high-dose of L. chagasi promastigotes was required for the development of protection against re-infection, whereas a low-dose immunization either had no effect or slightly exacerbated disease [49].

\subsection{Infectivity may influence downstream adaptive response-triggering events}

To understand the immune response behind this protective phenotype, we analyzed the splenic populations and the $\mathrm{T}$ cells functionality. We observed that infection with HL produced a significant increase in the total cellularity and major leukocyte populations when compared to naïve animals, which was not noticed when mice were infected with ST strain (Figure 2A-E). 

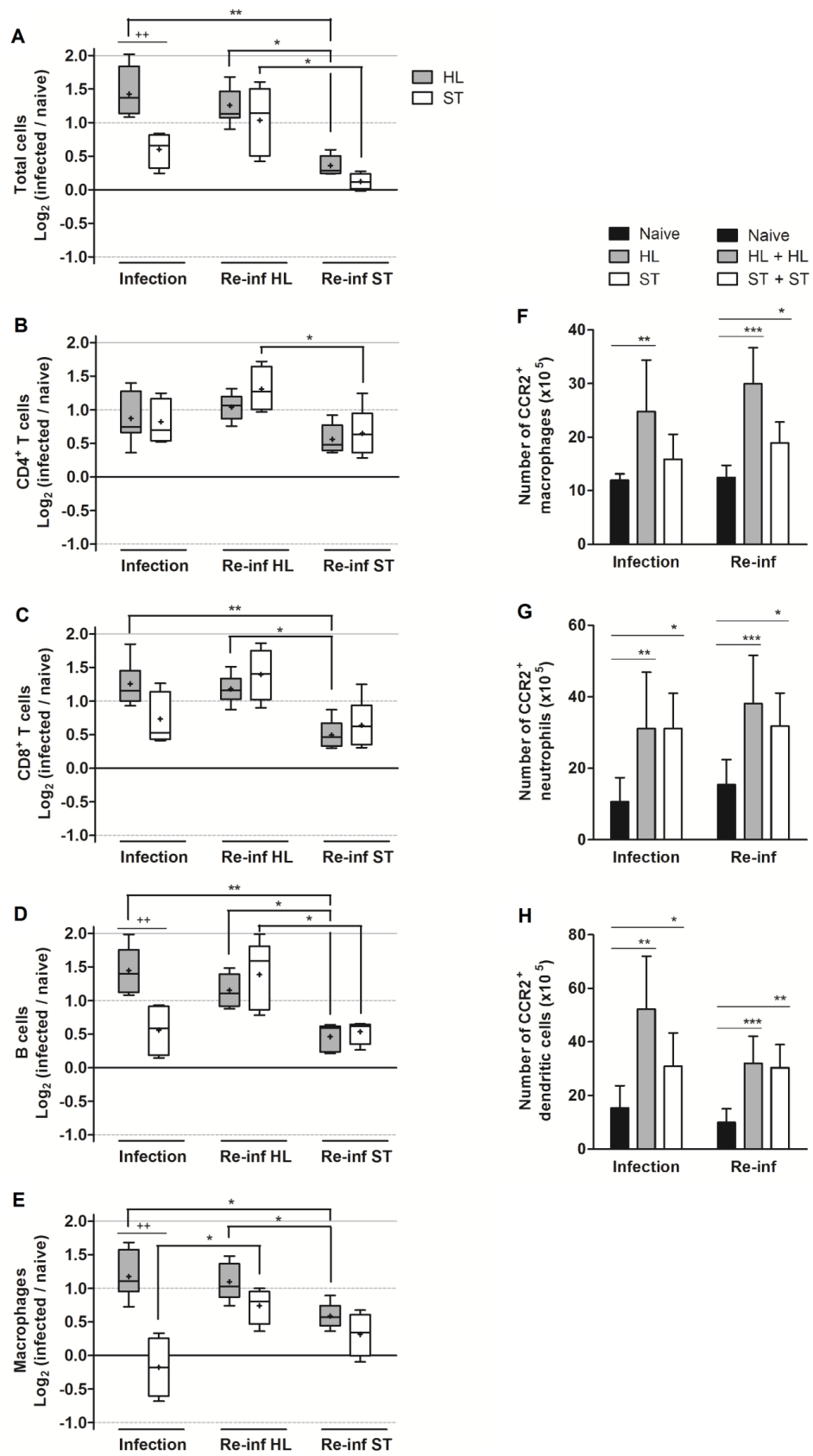

$\overline{(A-E) ~ A f t e r ~ i n f e c t i o n ~ a n d ~ c o n s e q u e n t ~ c h a l l e n g e ~ w i t h ~ b o t h ~ H L ~ a n d ~ S T ~ s t r a i n s, ~ s p l e n o c y t e s ~ w e r e ~ r e c o v e r e d ~ a n d ~ s u r f a c e-~}$ stained for identification of major leukocytes populations. (A) Total cells were counted and (B) CD4 $4^{+} \mathrm{T}_{\text {cells }}$

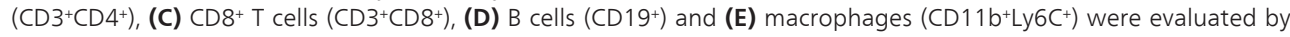


flow cytometry in a FACSCanto (BD Bioscences). Cell numbers from infected mice were normalized with respective values from age-matched naïve mice and results are presented as $\log _{2}$ of the fold change relative to naïve animals, with dashed and solid lines indicating 2- and 4-fold difference. Boxes and whiskers with 5-95 percentile and mean (showed with +) of 5 to 9 animals of one experiment representative of two independent. Mann-Whitney test was run to calculate statistically significant differences between mice infected with $\mathrm{HL}$ or ST and results are depicted with +. Differences before and after challenge are indicated with * for $p<0.05$ or ** for $p<0.01$ and were calculated with Kruskall-Wallis test followed by Dunn's multiple comparison test in GraphPad Prism 5 (GraphPad Software). (F-H) Number of (F) inflammatory macrophages (CD11 b+Ly6C+ CCR2 $\left.{ }^{+}\right)$, (G) inflammatory neutrophils (CD11 b+Ly6G+CCR2 ${ }^{+}$) and (H) activated dendritic cells (CD11 $\left.\mathrm{C}^{+} \mathrm{CCR} 2^{+}\right)$in infected mice before (Infection bars) and after homologous challenge (Re-inf bars). Bars represent means \pm SD of 5 to 9 animals of one experiment representative of two independent. Statistically significant differences were calculated in GraphPad Prism 5 (GraphPad Software) with Mann-Whitney test between naïve and infected or challenged animals and show ${ }^{*} p<0.05,{ }^{* *} p<0.01$ and ${ }^{* *} p<0.001$.

Figure 2. Splenic cellular populations after infection and challenge with highly and low infective $L$. infantum strains

Interestingly, when the animals were subjected to a secondary infection by HL, regardless of the infectivity of the imprinting strain, we detected the same increase in the number of splenocytes, while after challenge with ST there was no change in the cellularity.

Inflammatory macrophages/monocytes and neutrophils, besides its recognition as host cells $[137,138]$, have been implicated in the remodeling of the spleen during splenomegaly in leishmaniasis [139, 140], as well as in the modulation of the specific CD4 ${ }^{+} \mathrm{T}$ cells response in late phases of infection, at least with L. major [141]. Infiltration of neutrophils [142], DCs [143] and macrophages [144] in inflamed tissues is tightly regulated by the CC chemokine receptor 2 (CCR2) that also participates in important processes related to antiLeishmania defense [143, 144].

As these are the first cells that need to be committed, we determined the number of inflammatory macrophages, DCs and neutrophils by the expression of CCR2 (Figure 2F-H). Infection and challenge with HL led to the significant increase of these inflammatory cells in the spleen. Similarly, infection with ST also significantly increased the inflammatory DCs and neutrophils, but only with a second wave of parasites the CCR2 $2^{+}$macrophages arisen in numbers significantly higher than in uninfected animals. However, this difference in the number of CCR2 ${ }^{+}$ macrophages relates with the total macrophages present in the spleen, as the relative percentages were similar between HL and ST (data not shown). These CCR2 ${ }^{+}$macrophages exert an important role in the defense against Leishmania, since it has been previously described that optimal parasite killing require the recruitment of CCR2+ macrophages, followed by stimulation with combined monocyte chemotactic protein 1 (MCP-1) and IFN $\gamma$ [144].

Thus, monocyte and neutrophil activation showed no major differences between HL and ST strains, similarly to the findings of Meddeb-Garnaoui et al. that compared the cytokine profile of human monocytes infected with dermotropic and viscerotropic L. infantum strains which presented respectively high and low infectivity in vitro [145]. In their in vitro setup, no differences were found in the ability of those two strains in the modulation of monocytesecreted cytokines [145], indicating that the infectivity of a Leishmania strain not always produces a direct effect on the innate immune response. Nonetheless, in vivo, where other factors that influence macrophage function are present, the effect of the infectivity was not evaluated. We hypothesize that despite monocyte and neutrophil activation were similar, HLand ST-activated cells should present divergent efficiencies when triggering the adaptive 
immune response, which may be indicative of intrinsic characteristics of the strains in modulating downstream events.

\subsection{Highly infective L. infantum triggers memory and effector $\mathrm{CD}^{+}$and $\mathrm{CD} 8^{+} \mathrm{T}$ cells}

We have studied the generation of $\mathrm{CD}^{+}$and $\mathrm{CD}^{+}$memory $\mathrm{T}$ cells 6 weeks post-infection and upon challenge with the same strain by the surface expression of CD44 and CD62L (Figure 3).

A

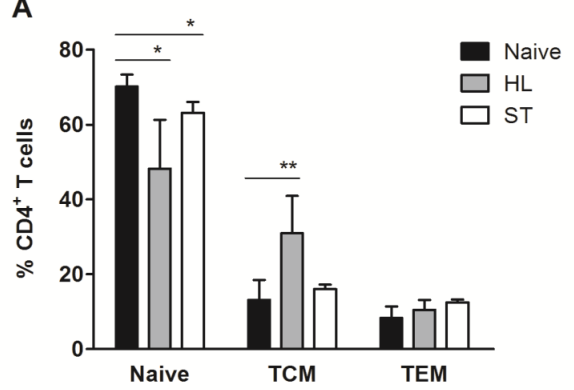

C

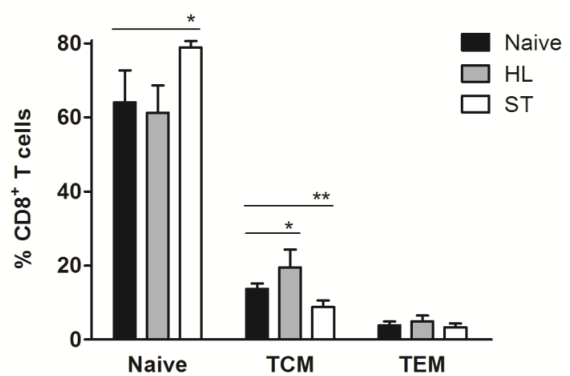

B

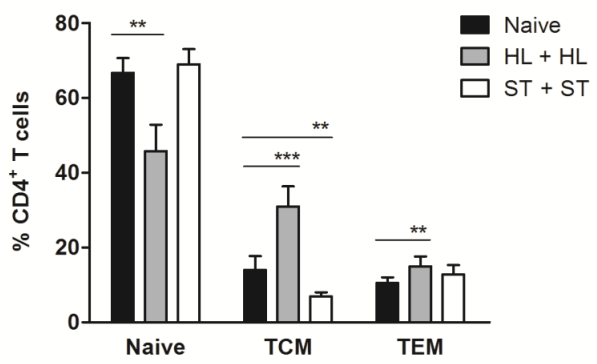

D

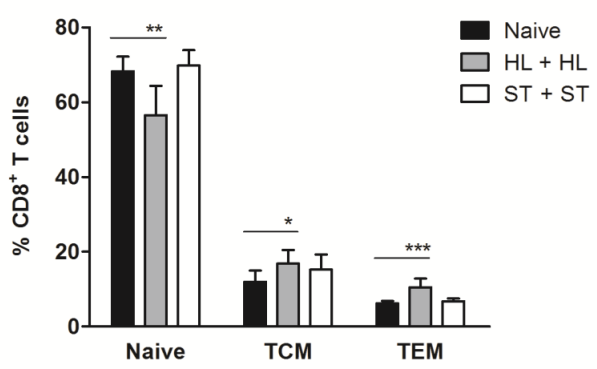

$\overline{(A, B) ~ C D 4+~ a n d ~(C, ~ D) ~ C D 8 ~}{ }^{+}$T cells were analyzed by flow cytometry in a FACSCanto (BD Bioscences) according to their surface expression of $C D 44$ and $C D 62 \mathrm{~L}$. Naïve (CD44 $\left.{ }^{\circ} \mathrm{CD} 62 \mathrm{~L}^{*}\right)$, central memory (TCM; CD44 $\left.4^{\mathrm{h}} \mathrm{CD} 62 \mathrm{~L}^{*}\right)$ and effector memory (TEM; CD44"CD62L) subpopulations were quantified before $(\mathbf{A}, \mathbf{C})$ and after (B, D) challenge. Bars show means \pm SD of 5 to 9 animals of one experiment representative of two independent and statistically significant differences between naïve and infected mice are depicted with * for $p<0.05$, as calculated by two-tailed Mann Whitney test run in GraphPad Prism 5 (GraphPad Software).

Figure 3. T cell memory repertoire of mice subjected to infection and homologous re-infection with HL and ST L. infantum strains

HL infection potentiated the expansion of central memory CD8 $8^{+}$(Figure 3C, TCM bars) and especially $\mathrm{CD}^{+} \mathrm{T}$ cells (Figure $3 \mathrm{~A}$, TCM bars) that doubled in percentage compared to uninfected mice. These memory populations are probably an important factor in the control of the parasite load in the spleen, as presented before (Figure 1A), when the animals were subjected to re-infection. Memory cells constitute a source of experienced-antigen cells that are 
able to rapidly respond to face a similar challenge. While TEM cells display protective effector functions, TCM are thought to replenish the TEM pool [146].

In fact, after challenge with HL, both $\mathrm{CD}^{+}$(Figure 3B) and $\mathrm{CD}^{+}$(Figure 3D) TCM pools remained high and TEM cells also significantly increased compared to naïve mice. Moreover, taking into account that the total numbers of $\mathrm{T}$ lymphocytes in the infected animals were significantly increased in relation to naïve mice (Figure $2 \mathrm{~B}$ and $\mathrm{C}$ ), the number of memory $\left(C D 44^{\text {hi }}\right)$ T cells was even more expressive in the spleens of those HL re-infected animals. On the contrary, ST strain showed no potential in clonal expansion of memory populations or at least in their high number maintenance in order to bring advantage upon re-infection. Neither in the imprinting infection nor after challenge could we detect $C D 4^{+}$or $C D 8^{+}$central or effector memory $\mathrm{T}$ cells in a percentage higher than that of the naïve animals. The decrease in the $\mathrm{CD}^{+}$TCM cells 6 weeks after ST infection (Figure 3C) was considered not to have any biological meaning since, when adjusted to total number of cells, both naïve and infected mice have similar amounts of that subpopulation.

From the data exposed, we justified the partial protection that a primary infection with HL $L$. infantum strain can generate upon an homologous re-infection. This strain has the ability to activate the innate defenders (DCs, macrophages and neutrophils) for mobilization to the spleen where they can drive an effective generation and expansion of memory $\mathrm{CD} 4^{+}$and $\mathrm{CD} 8^{+} \mathrm{T}$ cell subsets.

\subsection{Double producers $\mathrm{CD} 4^{+} \mathrm{IFN} \gamma^{+} \mathrm{IL}-10^{+}$and $\mathrm{CD} 8^{+} \mathrm{IFN} \gamma^{+} \mathrm{TNF} \alpha^{+} \mathrm{T}$ cells arise after re-infection}

To appreciate the mechanisms underlying the protection observed after re-infection with a highly infective strain, we analyzed the magnitude of the developed $\mathrm{T}$ cell response in infected and re-infected mice with HL strain. After infection, we detected high levels of IFN $\gamma$-producing $\mathrm{CD}^{+}$and $\mathrm{CD} 8^{+} \mathrm{T}$ cells (Figures $4 \mathrm{~A}$ and $\mathrm{C}$, respectively). This finding was suspected after having noticed the massive cellular infiltrate of leukocytes in the spleen (Figure 2) and also the existence of approximately $15 \%$ of effector memory lymphocytes (combined CD4 ${ }^{+}$and CD8 ${ }^{+}$) that classically secrete this cytokine [147]. Upon re-infection (Figures 4B and D), however, a more interesting panel of effector cells has emerged. Along with the same IFN $\gamma^{+}$cells, detected in both $\mathrm{CD}^{+}$and $\mathrm{CD} 8^{+}$lymphocytes, we identified IL-10 $0^{+}$in $\sim 1.5 \%$ and IFN $\gamma^{+} \mathrm{IL}-10^{+}$double producers in $\sim 0.75 \%$ of the $\mathrm{CD}^{+} \mathrm{T}$ cells, which represent an increment of $\sim 1.7$ and $\sim 3.1$, respectively, compared to uninfected animals.

$\mathrm{CD} 4^{+} \mathrm{T}-$ bet ${ }^{+} \mathrm{IFN} \gamma^{+} \mathrm{IL}-10^{+}$cells were recently described by us and others upon infection of BALB/ c mice with L. infantum [148] or L. donovani [149]. This Th1 population is driven by CD4 ${ }^{+} \mathrm{T}$ cells activation by the infected DCs and leads to an unprotective phenotype that accentuates the infection. However, a protective role was previously attributed to CD4 ${ }^{+} \mathrm{CD} 25$-Foxp3-IFN $\gamma$ ${ }^{+} \mathrm{IL}-10^{+}$cells in a vaccination study with L. donovani LdCen $1^{-/-}[57]$ and in a non-healing model of CL with $L$. major [150], which were claimed to arise after a strong inflammatory stimulus as a feedback control of Th1 responses to avoid tissue damage.

In $\mathrm{CD}^{+} \mathrm{T}$ cells, conversely, cytokine double producing cells were found for IFN $\gamma^{+} \mathrm{TNF} \alpha^{+}$, in a representation of $\sim 0.86 \%$, meaning an increase of $\sim 3.4$ fold compared to naïve mice. IFN $\gamma$ and 
A

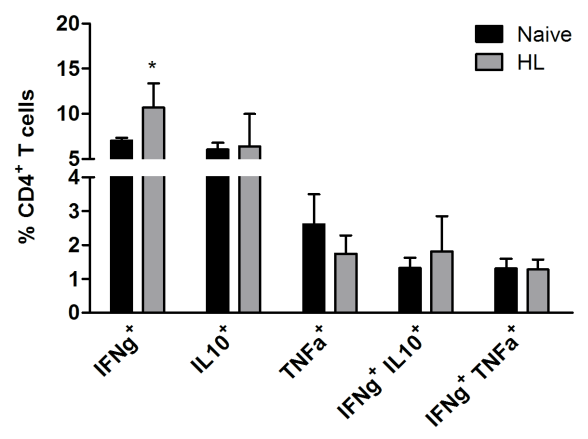

C

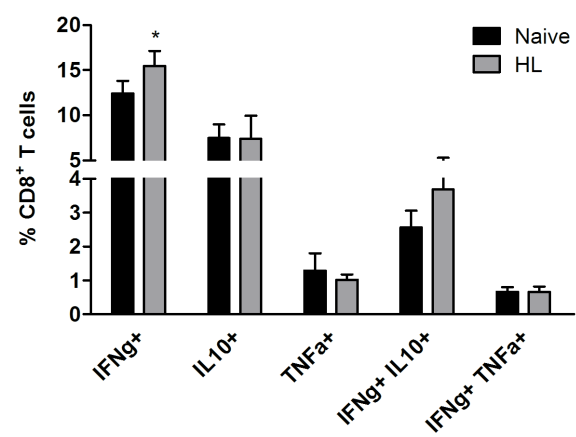

B

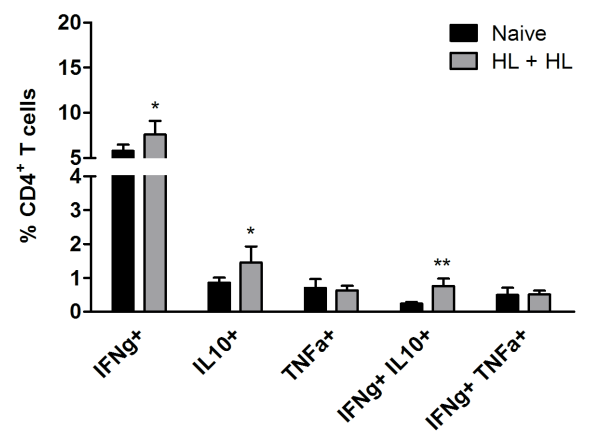

D

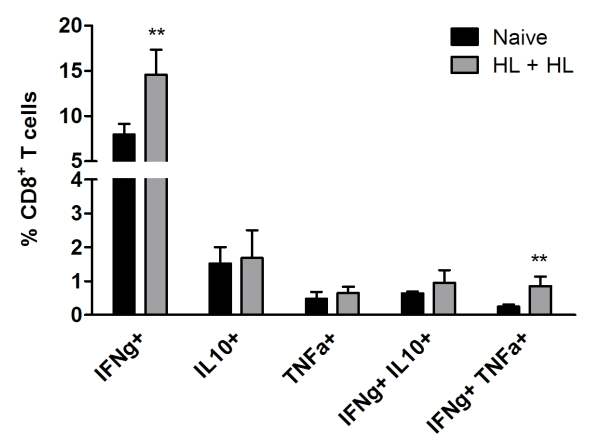

$\overline{\mathrm{IFN}}$, IL-10 and TNFa production was analyzed by flow cytometry in CD4 (A, B) and CD8 (C, D) lymphocytes. Splenocytes were stimulated ex-vivo with phorbol 12-myristate 13-acetate (PMA), ionomycin and brefeldin A, stained for surface and intracellular molecules and analyzed in a FACSCanto flow cytometer (BD Bioscences). Cytokine single and double producers in each lymphocyte population are depicted from naïve, infected $(\mathbf{A}, \mathbf{C})$ or challenged $(\mathbf{B}, \mathbf{D})$ mice. Bars represent means \pm SD of 4 to 9 animals of one experiment with statistically significant differences between naive and infected mice indicated with * when $\mathrm{p}<0.05$, as calculated by two-tailed Mann Whitney test run in GraphPad Prism 5 (GraphPad Software).

Figure 4. Intracellular cytokines of $\mathrm{CD}^{+}$and $\mathrm{CD} 8^{+}$lymphocytes of $\mathrm{HL}$ infected and re-infected animals

TNF $\alpha$ concomitant production by Th1 and CD8 ${ }^{+} \mathrm{T}$ cells has for long proven to be more efficient in the killing of L. major [151, 152] and other unrelated microorganisms (e.g. Mycobacterium tuberculosis [153]) than the production of IFN $\gamma$ or TNF $\alpha$ alone. More recently, IFN $\gamma^{+} \mathrm{TNF} \alpha^{+}$ high quality $\mathrm{CD}^{+}$and $\mathrm{CD} 8^{+} \mathrm{T}$ cells were described to be generated after several vaccination protocols against L. major and correlate with prognosis of protection much better than IFN $\gamma$ single producers [154]. Moreover, those double producers $\mathrm{CD}^{+} \mathrm{T}$ cells, which can also be IL-2 ${ }^{+}$, were determined to belong to the central memory subset, providing long-term protection $[154,155]$. As for $\mathrm{CD} 8^{+} \mathrm{IFN} \gamma^{+} \mathrm{TNF} \alpha^{+} \mathrm{T}$ cells, they were described to have enhanced cytolytic activity compared to IFN $\gamma^{+}$single producer cells in HIV-infected patients [156]. However, in our study, we could not detect any difference in the cytotoxicity mediated by CD ${ }^{+} \mathrm{T}$ cells from 
HL infected and challenged mice compared to that from naïve animals (data not shown), which may indicate that cytolytic activity of those cells was not required in the containment of the parasites in the spleen or, instead, the persistence of the splenic parasite load is due to an incomplete effector function of the $\mathrm{CD} 8^{+} \mathrm{T}$ cells.

\subsection{Conclusions}

Taken together, our results show that HL L. infantum strain promotes a robust activation of the immune system upon infection initiated by a strong recruitment of leukocytes to the spleen which stimulates the development of an effective adaptive response. This is a mixed response as considered by the detection of single producers IFN $\gamma^{+}$and IL- $10^{+} \mathrm{CD} 4^{+} \mathrm{T}$ cells that become more evident when the antigen is re-loaded (i. e. re-infection). $\mathrm{CD}^{+} \mathrm{T}$ cells also exert their effector function by the production of IFN $\gamma$. After re-infection, double producers CD8 ${ }^{+} \mathrm{IFN} \gamma$ ${ }^{+} \mathrm{TNF} \alpha^{+}$and $\mathrm{CD} 44^{+} \mathrm{IFN} \gamma^{+} \mathrm{IL}-10^{+} \mathrm{T}$ cells arise, probably from the expansion of the central and effector memory subsets, to contain the parasites that colonized the spleen and to efficiently resolve the infection in the liver and bone marrow, controlling tissue damage by IL-10 production. To confirm this hypothesis, adoptive transfer of these memory cells produced after re-infection with our highly infective $L$. infantum strain could be performed to evaluate the protective phenotype of such pools of $\mathrm{CD} 4^{+}$and $\mathrm{CD} 8^{+} \mathrm{T}$ cells in naïve animals challenged with a subsequent $L$. infantum infection.

Taking the fact that HL is a dermotropic strain that caused CL in a human patient, its tropism is possibly justified by the inflammatory potential of the strain that impedes a silent entry into the host. A protective response may immediately be mounted in the skin, abrogating any chance of the parasite to reach internal organs and visceralize [157]. Concerning the ST strain, an agent of human VL, the initial activation of the innate immune system does not translate into efficient adaptive immunity as no memory cells were detected. With this, a primary infection does not serve as imprinting, since a re-infection with the same strain led to the increase of the parasite load in the spleen and liver.

With this work we contributed to the better understanding of the complex modulation that Leishmania parasites do to surmount the protective strategies developed by the host's immune system. Much of the knowledge acquired so far by the scientific community was based on $L$. major-infection models that have a clear Th1/Th2 dichotomy on protection/progression of the disease, and more studies with VL models are needed to clarify the intriguing modulation that viscerotropic Leishmania strains provide to take advantage of their host.

\section{Final remarks}

Leishmaniasis is a tropical neglected disease that urgently needs control measures, as vaccination, since nowadays the global population is at risk. As some vaccines are available for $\mathrm{ZVL}$, the discovery of an effective human vaccine for VL is near. Choosing the right antigen coupled with the appropriate adjuvant for the formulation is crucial to have an effective vaccine, but immunogenicity sometimes countervail safety and complicates the scenario. 
Effective immunization requires the presentation of the antigen by proper APCs to mount a strong immune response and develop immunological memory, as well as it entails antigen persistence. As described previously, live vaccines produce more robust immune responses than dead parasites or defined protein or peptides but they represent an important health risk, mainly in immunosuppressed people. Furthermore, the immune response developed against live Leishmania infantum strains that display differences in infectivity is also unique and characteristic of each strain, being infectivity related with a stronger induction of an immune response, as showed by our experimental data.

In this chapter, we have updated the main aspects to consider when a vaccination study against Leishmania is planned. We aimed to show that vaccination is an effective way, and hopefully a soon reality, to prevent the spread of leishmaniasis, limiting the outcome of the disease and avoiding the parasite transmission. While successful research is close, many efforts are still needed for achieving an efficient human vaccine for leishmaniasis accessible to everyone in need.

\section{Abbreviations}

ALM autoclaved Leishmania major

APCs antigen presenting cells

CL cutaneous leishmaniasis

IL interleukin

MCL mucocutaneous leishmaniasis

MPL purified derivative of the monophosphoryl lipid A

NO nitric oxide

PAMP pathogen-associated molecular pattern

PBMCs peripheral blood mononuclear cells

SE squalene-based oil-in-water stable emulsion

TCM central memory T cell

TCR T cell receptor

TEM effector memory $\mathrm{T}$ cell

TLR Toll-like receptor

VL visceral leishmaniasis

ZVL zoonotic visceral leishmaniasis 


\section{Acknowledgements}

We thank Doctor Maria da Luz Duarte from São Marcos Hospital, Braga, Portugal, for kindly providing us the skin sample infected with HL strain of L. infantum. We thank Joana Tavares from the Parasite Disease Group, IBMC, Porto, Portugal, for the isolation of HL strain and preparation of live stocks and Carmen Chicharro from WHO Collaborating Center for Leishmaniasis, National Center of Microbiology, Instituto de Salud Carlos III, Majadahonda, Spain, for analyzing its zymodeme. We thank Ricardo Silvestre and Mariana Resende from the Parasite Disease Group, IBMC, Porto, Portugal, for the help in animal experiments and flow cytometry analysis.

This work was funded by FEDER funds through the Operational Competitiveness Programme - COMPETE and by National Funds through FCT - Fundação para a Ciência e a Tecnologia under the projects FCOMP-01-0124-FEDER-019648 (PTDC/BIA-MIC/118644/2010) and FCOMP-01-0124-FEDER-011058 (PTDC/SAU-FCF/101017/2008) as well as the MICINN's project number PIM2010-ENI00627. The research leading to these results has also received funding from the European Community's Seventh Framework Programme under grant agreement No.603181 (Project MuLeVaClin).

\section{Author details}

Joana Cunha ${ }^{1}$, Eugenia Carrillo², Javier Moreno ${ }^{2}$ and Anabela Cordeiro-da-Silva ${ }^{3^{*}}$

${ }^{*}$ Address all correspondence to: cordeiro@ibmc.up.pt

1 Parasite Disease Group, IBMC - Institute for Molecular and Cellular Biology, Institute for Biomedical Sciences Abel Salazar and Faculty of Medicine, University of Porto, Porto, Portugal

2 WHO Collaborating Center for Leishmaniasis, National Center for Microbiology, Instituto de Salud Carlos III, Majadahonda, Madrid, Spain

3 Parasite Disease Group, IBMC - Institute for Molecular and Cellular Biology and Laboratory of Microbiology, Department of Biological Sciences, Faculty of Pharmacy, University of Porto, Porto, Portugal

\section{References}

[1] WHO. Initiative for Vaccine Research (IVR). Parasitic Diseases. Malaria. 2013. Available from: http://www.who.int/vaccine_research/diseases/soa_parasitic/en/ index4.html. 
[2] Zaph C, Uzonna J, Beverley SM, Scott P. Central Memory T Cells Mediate LongTerm Immunity to Leishmania major in the Absence of Persistent Parasites. Nat Med. 2004 Oct;10(10):1104-1110. PubMed PMID: 15448686.

[3] Uzonna JE, Wei G, Yurkowski D, Bretscher P. Immune Elimination of Leishmania major in Mice: Implications for Immune Memory, Vaccination, and Reactivation Disease. J Immunol. 2001 Dec 15;167(12):6967-6974. PubMed PMID: 11739516.

[4] Alvar J, Velez ID, Bern C, Herrero M, Desjeux P, Cano J, et al. Leishmaniasis Worldwide and Global Estimates of Its Incidence. PLoS One. 2012;7(5):e35671. PubMed PMID: 22693548. Pubmed Central PMCID: 3365071.

[5] Michel G, Pomares C, Ferrua B, Marty P. Importance of Worldwide Asymptomatic Carriers of Leishmania infantum (L. chagasi) in Human. Acta Trop. 2011 Aug;119(2-3): 69-75. PubMed PMID: 21679680.

[6] Chappuis F, Sundar S, Hailu A, Ghalib H, Rijal S, Peeling RW, et al. Visceral Leishmaniasis: What Are the Needs for Diagnosis, Treatment and Control? Nat Rev Microbiol. 2007 Nov;5(11):873-882. PubMed PMID: 17938629.

[7] WHO. World Health Organization Web Page on Leishmaniasis. Burden of the Disease. 2013. Available from: http://www.who.int/leishmaniasis/burden/en/.

[8] WHO. Report of the Fifth Consultative Meeting on Leishmania/HIV Co-Infection. Addis Ababa, Ethiopia. 2007.

[9] Alvar J, Aparicio P, Aseffa A, Den Boer M, Canavate C, Dedet JP, et al. The Relationship between Leishmaniasis and AIDS: The Second 10 Years. Clin Microbiol Rev. 2008 Apr;21(2):334-359, table of contents. PubMed PMID: 18400800. Pubmed Central PMCID: 2292576.

[10] Ready PD. Leishmaniasis Emergence in Europe. Euro Surveill. 2010 Mar 11;15(10): 19505. PubMed PMID: 20403308.

[11] Rivas L, Moreno J, Canavate C, Alvar J. Virulence and Disease in Leishmaniasis: What Is Relevant for the Patient? Trends Parasitol. 2004 Jul;20(7):297-301. PubMed PMID: 15193556.

[12] Liese J, Schleicher U, Bogdan C. The Innate Immune Response against Leishmania Parasites. Immunobiology. 2008;213(3-4):377-387. PubMed PMID: 18406382.

[13] Silvestre R, Santarem N, Tavares J, Silva AM, Cordeiro-da-Silva A. Recognition of Leishmania Parasites by Innate Immunity. Immunology Endocrine \& Metabolic Agents - Medicinal Chemistry (Formerly Current Medicinal Chemistry - Immunology Endocrine \& Metabolic Agents). 2009 //;9(2):106-127.

[14] Tomioka H, Tatano Y, Maw WW, Sano C, Kanehiro Y, Shimizu T. Characteristics of Suppressor Macrophages Induced by Mycobacterial and Protozoal Infections in Relation to Alternatively Activated M2 Macrophages. Clin Dev Immunol. 2012;2012:635451. PubMed PMID: 22666284. Pubmed Central PMCID: 3361169. 
[15] Raes G, Beschin A, Ghassabeh GH, De Baetselier P. Alternatively Activated Macrophages in Protozoan Infections. Curr Opin Immunol. 2007 Aug;19(4):454-459. PubMed PMID: 17628461.

[16] Surh CD, Boyman O, Purton JF, Sprent J. Homeostasis of Memory T Cells. Immunol Rev. 2006 Jun;211:154-163. PubMed PMID: 16824125.

[17] Keshavarz Valian H, Nateghi Rostami M, Tasbihi M, Miramin Mohammadi A, Eskandari SE, Sarrafnejad A, et al. CCR7 Central and CCR7 Effector Memory CD4 T Cells in Human Cutaneous Leishmaniasis. J Clin Immunol. 2013 Jan;33(1):220-234. PubMed PMID: 22990666.

[18] Belkaid Y, Piccirillo CA, Mendez S, Shevach EM, Sacks DL. CD4 CD25 Regulatory T Cells Control Leishmania major Persistence and Immunity. Nature. 2002 Dec 5;420(6915):502-507. PubMed PMID: 12466842.

[19] Berrahal F, Mary C, Roze M, Berenger A, Escoffier K, Lamouroux D, et al. Canine Leishmaniasis: Identification of Asymptomatic Carriers by Polymerase Chain Reaction and Immunoblotting. Am J Trop Med Hyg. 1996 Sep;55(3):273-277. PubMed PMID: 8842114.

[20] Solano-Gallego L, Morell P, Arboix M, Alberola J, Ferrer L. Prevalence of Leishmania infantum Infection in Dogs Living in an Area of Canine Leishmaniasis Endemicity Using Pcr on Several Tissues and Serology. J Clin Microbiol. 2001 Feb;39(2):560-563. PubMed PMID: 11158106. Pubmed Central PMCID: 87775.

[21] Oliva G, Scalone A, Foglia Manzillo V, Gramiccia M, Pagano A, Di Muccio T, et al. Incidence and Time Course of Leishmania infantum Infections Examined by Parasitological, Serologic, and Nested-PCR Techniques in a Cohort of Naive Dogs Exposed to Three Consecutive Transmission Seasons. J Clin Microbiol. 2006 Apr;44(4):1318-1322. PubMed PMID: 16597857. Pubmed Central PMCID: 1448675.

[22] Quinnell RJ, Courtenay O. Transmission, Reservoir Hosts and Control of Zoonotic Visceral Leishmaniasis. Parasitology. 2009 Dec;136(14):1915-1934. PubMed PMID: 19835643.

[23] Cruz I, Acosta L, Gutierrez MN, Nieto J, Canavate C, Deschutter J, et al. A Canine Leishmaniasis Pilot Survey in an Emerging Focus of Visceral Leishmaniasis: Posadas (Misiones, Argentina). BMC Infect Dis. 2010;10:342. PubMed PMID: 21122107. Pubmed Central PMCID: 3002360.

[24] Maia-Elkhoury AN, Alves WA, Sousa-Gomes ML, Sena JM, Luna EA. Visceral Leishmaniasis in Brazil: Trends and Challenges. Cad Saude Publica. 2008 Dec;24(12): 2941-2947. PubMed PMID: 19082286.

[25] Maroli M, Rossi L, Baldelli R, Capelli G, Ferroglio E, Genchi C, et al. The Northward Spread of Leishmaniasis in Italy: Evidence from Retrospective and Ongoing Studies on the Canine Reservoir and Phlebotomine Vectors. Trop Med Int Health. 2008 Feb; 13(2):256-264. PubMed PMID: 18304273. 
[26] Alvar J, Canavate C, Molina R, Moreno J, Nieto J. Canine Leishmaniasis. Adv Parasitol. 2004;57:1-88. PubMed PMID: 15504537.

[27] Moreno J, Alvar J. Canine Leishmaniasis: Epidemiological Risk and the Experimental Model. Trends Parasitol. 2002 Sep;18(9):399-405. PubMed PMID: 12377257.

[28] Manna L, Reale S, Viola E, Vitale F, Foglia Manzillo V, Pavone LM, et al. Leishmania DNA Load and Cytokine Expression Levels in Asymptomatic Naturally Infected Dogs. Vet Parasitol. 2006 Dec 20;142(3-4):271-280. PubMed PMID: 16920264.

[29] Chamizo C, Moreno J, Alvar J. Semi-Quantitative Analysis of Cytokine Expression in Asymptomatic Canine Leishmaniasis. Vet Immunol Immunopathol. 2005 Jan 10;103(1-2):67-75. PubMed PMID: 15626462.

[30] Carrillo E, Ahmed S, Goldsmith-Pestana K, Nieto J, Osorio Y, Travi B, et al. Immunogenicity of the P-8 Amastigote Antigen in the Experimental Model of Canine Visceral Leishmaniasis. Vaccine. 2007 Feb 9;25(8):1534-1543. PubMed PMID: 17178178. Pubmed Central PMCID: 2571115.

[31] Strauss-Ayali D, Baneth G, Shor S, Okano F, Jaffe CL. Interleukin-12 Augments a Th1-Type Immune Response Manifested as Lymphocyte Proliferation and Interferon Gamma Production in Leishmania infantum-Infected Dogs. Int J Parasitol. 2005 Jan; 35(1):63-73. PubMed PMID: 15619517.

[32] Carrillo E, Crusat M, Nieto J, Chicharro C, Thomas Mdel C, Martinez E, et al. Immunogenicity of HSP-70, KMP-11 and PFR-2 Leishmanial Antigens in the Experimental Model of Canine Visceral Leishmaniasis. Vaccine. 2008 Mar 28;26(15):1902-1911. PubMed PMID: 18321614.

[33] Deplazes P, Smith NC, Arnold P, Lutz H, Eckert J. Specific Igg1 and Igg2 Antibody Responses of Dogs to Leishmania infantum and Other Parasites. Parasite Immunol. 1995 Sep;17(9):451-458. PubMed PMID: 8552413.

[34] Solano-Gallego L, Riera C, Roura X, Iniesta L, Gallego M, Valladares JE, et al. Leishmania infantum-Specific IgG, IgG1 and IgG2 Antibody Responses in Healthy and Ill Dogs from Endemic Areas. Evolution in the Course of Infection and after Treatment. Vet Parasitol. 2001 Apr 19;96(4):265-276. PubMed PMID: 11267753.

[35] Quinnell RJ, Courtenay O, Garcez LM, Kaye PM, Shaw MA, Dye C, et al. IgG Subclass Responses in a Longitudinal Study of Canine Visceral Leishmaniasis. Vet Immunol Immunopathol. 2003 Feb 10;91(3-4):161-168. PubMed PMID: 12586479.

[36] Bourdoiseau G, Hugnet C, Goncalves RB, Vezilier F, Petit-Didier E, Papierok G, et al. Effective Humoral and Cellular Immunoprotective Responses in Li ESAp-MDP Vaccinated Protected Dogs. Vet Immunol Immunopathol. 2009 Mar 15;128(1-3):71-78. PubMed PMID: 19046774.

[37] Moreno J, Nieto J, Chamizo C, Gonzalez F, Blanco F, Barker DC, et al. The Immune Response and PBMC Subsets in Canine Visceral Leishmaniasis before, and after, 
Chemotherapy. Vet Immunol Immunopathol. 1999 Nov 30;71(3-4):181-195. PubMed PMID: 10587300.

[38] Handman E. Leishmaniasis: Current Status of Vaccine Development. Clin Microbiol Rev. 2001 Apr;14(2):229-243. PubMed PMID: 11292637. Pubmed Central PMCID: 88972.

[39] Melby PC, Chandrasekar B, Zhao W, Coe JE. The Hamster as a Model of Human Visceral Leishmaniasis: Progressive Disease and Impaired Generation of Nitric Oxide in the Face of a Prominent Th1-Like Cytokine Response. J Immunol. 2001 Feb 1;166(3): 1912-1920. PubMed PMID: 11160239.

[40] Abranches P, Santos-Gomes G, Rachamim N, Campino L, Schnur LF, Jaffe CL. An Experimental Model for Canine Visceral Leishmaniasis. Parasite Immunol. 1991 Sep; 13(5):537-550. PubMed PMID: 1956700.

[41] Porrozzi R, Pereira MS, Teva A, Volpini AC, Pinto MA, Marchevsky RS, et al. Leishmania infantum-Induced Primary and Challenge Infections in Rhesus Monkeys (Macaca mulatta): A Primate Model for Visceral Leishmaniasis. Trans R Soc Trop Med Hyg. 2006 Oct;100(10):926-937. PubMed PMID: 16455120.

[42] Mutiso JM, Macharia JC, Taracha E, Gicheru MM. Leishmania donovani Whole Cell Antigen Delivered with Adjuvants Protects against Visceral Leishmaniasis in Vervet Monkeys (Chlorocebus aethiops). J Biomed Res. 2012 Jan;26(1):8-16. PubMed PMID: 23554725. Pubmed Central PMCID: 3596075.

[43] Dube A, Sharma P, Srivastava JK, Misra A, Naik S, Katiyar JC. Vaccination of Langur Monkeys (Presbytis entellus) against Leishmania donovani with Autoclaved L. major Plus BCG. Parasitology. 1998 Mar;116 ( Pt 3):219-221. PubMed PMID: 9550214.

[44] Misra A, Dube A, Srivastava B, Sharma P, Srivastava JK, Katiyar JC, et al. Successful Vaccination against Leishmania donovani Infection in Indian Langur Using Alum-Precipitated Autoclaved Leishmania major with BCG. Vaccine. 2001 May 14;19(25-26): 3485-3492. PubMed PMID: 11348715.

[45] Evans KJ, Kedzierski L. Development of Vaccines against Visceral Leishmaniasis. J Trop Med. 2012;2012:892817. PubMed PMID: 21912561. Pubmed Central PMCID: 3170777.

[46] Khamesipour A, Dowlati Y, Asilian A, Hashemi-Fesharki R, Javadi A, Noazin S, et al. Leishmanization: Use of an Old Method for Evaluation of Candidate Vaccines against Leishmaniasis. Vaccine. 2005 May 25;23(28):3642-3648. PubMed PMID: 15882524 .

[47] Karunaweera ND. Leishmania donovani Causing Cutaneous Leishmaniasis in Sri Lanka: A Wolf in Sheep's Clothing? Trends Parasitol. 2009 Oct;25(10):458-463. PubMed PMID: 19734098.

[48] McCall LI, Zhang WW, Ranasinghe S, Matlashewski G. Leishmanization Revisited: Immunization with a Naturally Attenuated Cutaneous Leishmania donovani Isolate 
from Sri Lanka Protects against Visceral Leishmaniasis. Vaccine. 2013 Feb 27;31(10): 1420-1425. PubMed PMID: 23219435.

[49] Streit JA, Recker TJ, Filho FG, Beverley SM, Wilson ME. Protective Immunity against the Protozoan Leishmania chagasi Is Induced by Subclinical Cutaneous Infection with Virulent but Not Avirulent Organisms. J Immunol. 2001 Feb 1;166(3):1921-1929. PubMed PMID: 11160240.

[50] Zijlstra EE, el-Hassan AM, Ismael A, Ghalib HW. Endemic Kala-Azar in Eastern Sudan: A Longitudinal Study on the Incidence of Clinical and Subclinical Infection and Post-Kala-Azar Dermal Leishmaniasis. Am J Trop Med Hyg. 1994 Dec;51(6):826-836. PubMed PMID: 7810819.

[51] Giunchetti RC, Correa-Oliveira R, Martins-Filho OA, Teixeira-Carvalho A, Roatt BM, de Oliveira Aguiar-Soares RD, et al. Immunogenicity of a Killed Leishmania Vaccine with Saponin Adjuvant in Dogs. Vaccine. 2007 Nov 1;25(44):7674-7686. PubMed PMID: 17913311.

[52] Armijos RX, Weigel MM, Aviles H, Maldonado R, Racines J. Field Trial of a Vaccine against New World Cutaneous Leishmaniasis in an at-Risk Child Population: Safety, Immunogenicity, and Efficacy During the First 12 Months of Follow-Up. J Infect Dis. 1998 May;177(5):1352-1357. PubMed PMID: 9593024.

[53] Noazin S, Khamesipour A, Moulton LH, Tanner M, Nasseri K, Modabber F, et al. Efficacy of Killed Whole-Parasite Vaccines in the Prevention of Leishmaniasis: A MetaAnalysis. Vaccine. 2009 Jul 30;27(35):4747-4753. PubMed PMID: 19540273.

[54] Das A, Ali N. Vaccine Prospects of Killed but Metabolically Active Leishmania against Visceral Leishmaniasis. Expert Rev Vaccines. 2012 Jul;11(7):783-785. PubMed PMID: 22913255.

[55] Breton M, Tremblay MJ, Ouellette M, Papadopoulou B. Live Nonpathogenic Parasitic Vector as a Candidate Vaccine against Visceral Leishmaniasis. Infect Immun. 2005 Oct;73(10):6372-6382. PubMed PMID: 16177308. Pubmed Central PMCID: 1230936.

[56] Papadopoulou B, Roy G, Breton M, Kundig C, Dumas C, Fillion I, et al. Reduced Infectivity of a Leishmania donovani Biopterin Transporter Genetic Mutant and Its Use as an Attenuated Strain for Vaccination. Infect Immun. 2002 Jan;70(1):62-68. PubMed PMID: 11748164. Pubmed Central PMCID: 127620.

[57] Selvapandiyan A, Dey R, Nylen S, Duncan R, Sacks D, Nakhasi HL. Intracellular Replication-Deficient Leishmania donovani Induces Long Lasting Protective Immunity against Visceral Leishmaniasis. J Immunol. 2009 Aug 1;183(3):1813-1820. PubMed PMID: 19592661.

[58] Dey R, Meneses C, Salotra P, Kamhawi S, Nakhasi HL, Duncan R. Characterization of a Leishmania Stage-Specific Mitochondrial Membrane Protein That Enhances the Activity of Cytochrome C Oxidase and Its Role in Virulence. Mol Microbiol. 2010 Jul; 77(2):399-414. PubMed PMID: 20497506. Pubmed Central PMCID: 2909329. 
[59] Silvestre R, Cordeiro-Da-Silva A, Santarem N, Vergnes B, Sereno D, Ouaissi A. Sir2Deficient Leishmania infantum Induces a Defined IFN-gamma/IL-10 Pattern That Correlates with Protection. J Immunol. 2007 Sep 1;179(5):3161-3170. PubMed PMID: 17709531 .

[60] Mizbani A, Taheri T, Zahedifard F, Taslimi Y, Azizi H, Azadmanesh K, et al. Recombinant Leishmania tarentolae Expressing the A2 Virulence Gene as a Novel Candidate Vaccine against Visceral Leishmaniasis. Vaccine. 2009 Dec 10;28(1):53-62. PubMed PMID: 19818721.

[61] Selvapandiyan A, Dey R, Gannavaram S, Lakhal-Naouar I, Duncan R, Salotra P, et al. Immunity to Visceral Leishmaniasis Using Genetically Defined Live-Attenuated Parasites. J Trop Med. 2012;2012:631460. PubMed PMID: 21912560. Pubmed Central PMCID: 3168768.

[62] Nagill R, Kaur S. Vaccine Candidates for Leishmaniasis: A Review. Int Immunopharmacol. 2011 Oct;11(10):1464-1488. PubMed PMID: 21616175.

[63] Russell DG, Alexander J. Effective Immunization against Cutaneous Leishmaniasis with Defined Membrane Antigens Reconstituted into Liposomes. J Immunol. 1988 Feb 15;140(4):1274-1279. PubMed PMID: 3257774.

[64] Bhowmick S, Ravindran R, Ali N. gp63 in Stable Cationic Liposomes Confers Sustained Vaccine Immunity to Susceptible BALB/c Mice Infected with Leishmania donovani. Infect Immun. 2008 Mar;76(3):1003-1015. PubMed PMID: 18195029. Pubmed Central PMCID: 2258822.

[65] Gurunathan S, Prussin C, Sacks DL, Seder RA. Vaccine Requirements for Sustained Cellular Immunity to an Intracellular Parasitic Infection. Nat Med. 1998 Dec;4(12): 1409-1415. PubMed PMID: 9846579.

[66] Coelho EA, Tavares CA, Carvalho FA, Chaves KF, Teixeira KN, Rodrigues RC, et al. Immune Responses Induced by the Leishmania (Leishmania) donovani A2 Antigen, but Not by the LACK Antigen, Are Protective against Experimental Leishmania (Leishmania) amazonensis Infection. Infect Immun. 2003 Jul;71(7):3988-3994. PubMed PMID: 12819086. Pubmed Central PMCID: 162020.

[67] Pinto EF, Pinheiro RO, Rayol A, Larraga V, Rossi-Bergmann B. Intranasal Vaccination against Cutaneous Leishmaniasis with a Particulated Leishmanial Antigen or DNA Encoding LACK. Infect Immun. 2004 Aug;72(8):4521-4527. PubMed PMID: 15271911. Pubmed Central PMCID: 470668.

[68] Handman E, Symons FM, Baldwin TM, Curtis JM, Scheerlinck JP. Protective Vaccination with Promastigote Surface Antigen 2 from Leishmania major Is Mediated by a Th1 Type of Immune Response. Infect Immun. 1995 Nov;63(11):4261-4267. PubMed PMID: 7591056. Pubmed Central PMCID: 173605.

[69] Sjolander A, Baldwin TM, Curtis JM, Bengtsson KL, Handman E. Vaccination with Recombinant Parasite Surface Antigen 2 from Leishmania major Induces a Th1 Type of 
Immune Response but Does Not Protect against Infection. Vaccine. 1998 Dec;16(20): 2077-2084. PubMed PMID: 9796067.

[70] Coler RN, Skeiky YA, Bernards K, Greeson K, Carter D, Cornellison CD, et al. Immunization with a Polyprotein Vaccine Consisting of the T-Cell Antigens Thiol-Specific Antioxidant, Leishmania major Stress-Inducible Protein 1, and Leishmania Elongation Initiation Factor Protects against Leishmaniasis. Infect Immun. 2002 Aug;70(8): 4215-4225. PubMed PMID: 12117930. Pubmed Central PMCID: 128156.

[71] Coler RN, Goto Y, Bogatzki L, Raman V, Reed SG. Leish-111f, a Recombinant Polyprotein Vaccine That Protects against Visceral Leishmaniasis by Elicitation of CD4 $\mathrm{T}$ Cells. Infect Immun. 2007 Sep;75(9):4648-4654. PubMed PMID: 17606603. Pubmed Central PMCID: 1951162.

[72] Velez ID, Gilchrist K, Martinez S, Ramirez-Pineda JR, Ashman JA, Alves FP, et al. Safety and Immunogenicity of a Defined Vaccine for the Prevention of Cutaneous Leishmaniasis. Vaccine. 2009 Dec 11;28(2):329-337. PubMed PMID: 19879995.

[73] Chakravarty J, Kumar S, Trivedi S, Rai VK, Singh A, Ashman JA, et al. A Clinical Trial to Evaluate the Safety and Immunogenicity of the Leish-F1+MPL-SE Vaccine for Use in the Prevention of Visceral Leishmaniasis. Vaccine. 2011 Apr 27;29(19): 3531-3537. PubMed PMID: 21414377.

[74] Trigo J, Abbehusen M, Netto EM, Nakatani M, Pedral-Sampaio G, de Jesus RS, et al. Treatment of Canine Visceral Leishmaniasis by the Vaccine Leish-111f+MPL-SE. Vaccine. 2010 Apr 26;28(19):3333-3340. PubMed PMID: 20206667. Pubmed Central PMCID: 2874835.

[75] Gradoni L, Foglia Manzillo V, Pagano A, Piantedosi D, De Luna R, Gramiccia M, et al. Failure of a Multi-Subunit Recombinant Leishmanial Vaccine (MML) to Protect Dogs from Leishmania infantum Infection and to Prevent Disease Progression in Infected Animals. Vaccine. 2005 Nov 1;23(45):5245-5251. PubMed PMID: 16054272.

[76] Miret J, Nascimento E, Sampaio W, Franca JC, Fujiwara RT, Vale A, et al. Evaluation of an Immunochemotherapeutic Protocol Constituted of N-Methyl Meglumine Antimoniate (Glucantime) and the Recombinant Leish-110f + MPL-SE Vaccine to Treat Canine Visceral Leishmaniasis. Vaccine. 2008 Mar 17;26(12):1585-1594. PubMed PMID: 18328956.

[77] Bertholet S, Goto Y, Carter L, Bhatia A, Howard RF, Carter D, et al. Optimized Subunit Vaccine Protects against Experimental Leishmaniasis. Vaccine. 2009 Nov 23;27(50):7036-7045. PubMed PMID: 19786136. Pubmed Central PMCID: 2783536.

[78] Duthie MS, Raman VS, Piazza FM, Reed SG. The Development and Clinical Evaluation of Second-Generation Leishmaniasis Vaccines. Vaccine. 2012 Jan 5;30(2):134-141. PubMed PMID: 22085553. Pubmed Central PMCID: 3359766.

[79] Molano I, Alonso MG, Miron C, Redondo E, Requena JM, Soto M, et al. A Leishmania infantum Multi-Component Antigenic Protein Mixed with Live BCG Confers Protec- 
tion to Dogs Experimentally Infected with L. infantum. Vet Immunol Immunopathol. 2003 Mar 20;92(1-2):1-13. PubMed PMID: 12628759.

[80] Parody N, Soto M, Requena JM, Alonso C. Adjuvant Guided Polarization of the Immune Humoral Response against a Protective Multicomponent Antigenic Protein (Q) from Leishmania infantum. A CPG + Q Mix Protects BALB/c Mice from Infection. Parasite Immunol. 2004 Jun-Jul;26(6-7):283-293. PubMed PMID: 15541032.

[81] Restifo NP, Ying H, Hwang L, Leitner WW. The Promise of Nucleic Acid Vaccines. Gene Ther. 2000 Jan;7(2):89-92. PubMed PMID: 10673713. Pubmed Central PMCID: 2241736.

[82] Dondji B, Perez-Jimenez E, Goldsmith-Pestana K, Esteban M, McMahon-Pratt D. Heterologous Prime-Boost Vaccination with the LACK Antigen Protects against Murine Visceral Leishmaniasis. Infect Immun. 2005 Aug;73(8):5286-5289. PubMed PMID: 16041057. Pubmed Central PMCID: 1201228.

[83] Gomes DC, Pinto EF, de Melo LD, Lima WP, Larraga V, Lopes UG, et al. Intranasal Delivery of Naked DNA Encoding the LACK Antigen Leads to Protective Immunity against Visceral Leishmaniasis in Mice. Vaccine. 2007 Mar 8;25(12):2168-2172. PubMed PMID: 17240003.

[84] Ramos I, Alonso A, Marcen JM, Peris A, Castillo JA, Colmenares M, et al. Heterologous Prime-Boost Vaccination with a Non-Replicative Vaccinia Recombinant Vector Expressing LACK Confers Protection against Canine Visceral Leishmaniasis with a Predominant Th1-Specific Immune Response. Vaccine. 2008 Jan 17;26(3):333-344. PubMed PMID: 18093705.

[85] Tapia E, Perez-Jimenez E, Lopez-Fuertes L, Gonzalo R, Gherardi MM, Esteban M. The Combination of DNA Vectors Expressing IL-12 + IL-18 Elicits High Protective Immune Response against Cutaneous Leishmaniasis after Priming with DNA-P36/ LACK and the Cytokines, Followed by a Booster with a Vaccinia Virus Recombinant Expressing P36/LACK. Microbes Infect. 2003 Feb;5(2):73-84. PubMed PMID: 12650765.

[86] Perez-Jimenez E, Kochan G, Gherardi MM, Esteban M. MVA-LACK as a Safe and Efficient Vector for Vaccination against Leishmaniasis. Microbes Infect. 2006 Mar;8(3): 810-822. PubMed PMID: 16504562.

[87] Moll H, Berberich C. Dendritic Cells as Vectors for Vaccination against Infectious Diseases. Int J Med Microbiol. 2001 Nov;291(5):323-329. PubMed PMID: 11727816.

[88] Jardim A, Alexander J, Teh HS, Ou D, Olafson RW. Immunoprotective Leishmania major Synthetic T Cell Epitopes. J Exp Med. 1990 Aug 1;172(2):645-648. PubMed PMID: 1695670. Pubmed Central PMCID: 2188333.

[89] Tsagozis P, Karagouni E, Dotsika E. Dendritic Cells Pulsed with Peptides of gp63 Induce Differential Protection against Experimental Cutaneous Leishmaniasis. Int J Immunopathol Pharmacol. 2004 Sep-Dec;17(3):343-352. PubMed PMID: 15461868. 
[90] Agallou M, Smirlis D, Soteriadou KP, Karagouni E. Vaccination with Leishmania Histone H1-Pulsed Dendritic Cells Confers Protection in Murine Visceral Leishmaniasis. Vaccine. 2012 Jul 20;30(34):5086-5093. PubMed PMID: 22704924.

[91] Carrion J, Nieto A, Soto M, Alonso C. Adoptive Transfer of Dendritic Cells Pulsed with Leishmania infantum Nucleosomal Histones Confers Protection against Cutaneous Leishmaniosis in BALB/c Mice. Microbes Infect. 2007 May;9(6):735-743. PubMed PMID: 17400015.

[92] Agallou M, Margaroni M, Karagouni E. Cellular Vaccination with Bone Marrow-Derived Dendritic Cells Pulsed with a Peptide of Leishmania infantum KMP-11 and CPG Oligonucleotides Induces Protection in a Murine Model of Visceral Leishmaniasis. Vaccine. 2011 Jul 12;29(31):5053-5064. PubMed PMID: 21569815.

[93] Badiee A, Heravi Shargh V, Khamesipour A, Jaafari MR. Micro/Nanoparticle Adjuvants for Antileishmanial Vaccines: Present and Future Trends. Vaccine. 2013 Jan 21;31(5):735-749. PubMed PMID: 23219436.

[94] Jaafari MR, Ghafarian A, Farrokh-Gisour A, Samiei A, Kheiri MT, Mahboudi F, et al. Immune Response and Protection Assay of Recombinant Major Surface Glycoprotein of Leishmania (rgp63) Reconstituted with Liposomes in BALB/c Mice. Vaccine. 2006 Jul 17;24(29-30):5708-5717. PubMed PMID: 16740346.

[95] Badiee A, Jaafari MR, Khamesipour A. Leishmania Major: Immune Response in BALB/c Mice Immunized with Stress-Inducible Protein 1 Encapsulated in Liposomes. Exp Parasitol. 2007 Feb;115(2):127-134. PubMed PMID: 16979165.

[96] Bhowmick S, Ali N. Recent Developments in Leishmaniasis Vaccine Delivery Systems. Expert Opin Drug Deliv. 2008 Jul;5(7):789-803. PubMed PMID: 18590463.

[97] Bhowmick S, Mazumdar T, Ali N. Vaccination Route That Induces Transforming Growth Factor Beta Production Fails to Elicit Protective Immunity against Leishmania donovani Infection. Infect Immun. 2009 Apr;77(4):1514-1523. PubMed PMID: 19168736. Pubmed Central PMCID: 2663136.

[98] Kawai T, Akira S. The Role of Pattern-Recognition Receptors in Innate Immunity: Update on Toll-Like Receptors. Nat Immunol. 2010 May;11(5):373-384. PubMed PMID: 20404851.

[99] Gurunathan S, Sacks DL, Brown DR, Reiner SL, Charest H, Glaichenhaus N, et al. Vaccination with DNA Encoding the Immunodominant LACK Parasite Antigen Confers Protective Immunity to Mice Infected with Leishmania major. J Exp Med. 1997 Oct 6;186(7):1137-1147. PubMed PMID: 9314562. Pubmed Central PMCID: 2199076.

[100] Mendez S, Gurunathan S, Kamhawi S, Belkaid Y, Moga MA, Skeiky YA, et al. The Potency and Durability of DNA- and Protein-Based Vaccines against Leishmania major Evaluated Using Low-Dose, Intradermal Challenge. J Immunol. 2001 Apr 15;166(8): 5122-5128. PubMed PMID: 11290794. 
[101] Coler RN, Reed SG. Second-Generation Vaccines against Leishmaniasis. Trends Parasitol. 2005 May;21(5):244-249. PubMed PMID: 15837614.

[102] Raman VS, Duthie MS, Fox CB, Matlashewski G, Reed SG. Adjuvants for Leishmania Vaccines: From Models to Clinical Application. Front Immunol. 2012;3:144. PubMed PMID: 22701453. Pubmed Central PMCID: 3371596.

[103] Coler RN, Bertholet S, Moutaftsi M, Guderian JA, Windish HP, Baldwin SL, et al. Development and Characterization of Synthetic Glucopyranosyl Lipid Adjuvant System as a Vaccine Adjuvant. PLoS One. 2011;6(1):e16333. PubMed PMID: 21298114. Pubmed Central PMCID: 3027669.

[104] Klinman DM, Kamstrup S, Verthelyi D, Gursel I, Ishii KJ, Takeshita F, et al. Activation of the Innate Immune System by CPG Oligodeoxynucleotides: Immunoprotective Activity and Safety. Springer Semin Immunopathol. 2000;22(1-2):173-183. PubMed PMID: 10944812.

[105] Klinman DM, Yi AK, Beaucage SL, Conover J, Krieg AM. CPG Motifs Present in Bacteria DNA Rapidly Induce Lymphocytes to Secrete Interleukin 6, Interleukin 12, and Interferon gamma. Proc Natl Acad Sci U S A. 1996 Apr 2;93(7):2879-2883. PubMed PMID: 8610135. Pubmed Central PMCID: 39727.

[106] Novak N, Yu CF, Bieber T, Allam JP. Toll-Like Receptor 7 Agonists and Skin. Drug News Perspect. 2008 Apr;21(3):158-165. PubMed PMID: 18560614.

[107] Buates S, Matlashewski G. Treatment of Experimental Leishmaniasis with the Immunomodulators Imiquimod and S-28463: Efficacy and Mode of Action. J Infect Dis. 1999 Jun;179(6):1485-1494. PubMed PMID: 10228071.

[108] Hervas JA, Martin-Santiago A, Hervas D, Rojo E, Mena A, Rocamora V, et al. Old World Leishmania infantum Cutaneous Leishmaniasis Unresponsive to Liposomal Amphotericin B Treated with Topical Imiquimod. Pediatr Infect Dis J. 2012 Jan;31(1): 97-100. PubMed PMID: 21829140.

[109] Garcia Bustos MF, Barrio AB, Parodi Ramoneda CM, Ramos F, Mora MC, Convit J, et al. Immunological Correlates of Cure in the First American Cutaneous Leishmaniasis Patient Treated by Immunotherapy in Argentina. A Case Report. Invest Clin. 2011 Dec;52(4):365-375. PubMed PMID: 22523846.

[110] Nahrevanian H, Jafary SP, Nemati S, Farahmand M, Omidinia E. Evaluation of AntiLeishmanial Effects of Killed Leishmania Vaccine with BCG Adjuvant in BALB/c Mice Infected with Leishmania major MRHO/IR/75/ER. Folia Parasitol (Praha). 2013 Feb; 60(1):1-6. PubMed PMID: 23539946.

[111] Soudi S, Hosseini AZ, Hashemi SM. Co-Administration of Rectal BCG and Autoclaved Leishmania major Induce Protection in Susceptible BALB/c Mice. Parasite Immunol. 2011 Oct;33(10):561-571. PubMed PMID: 21781137.

[112] Nateghi Rostami M, Keshavarz H, Khamesipour A. Immune Response of BALB/C Mice against an Experimental Vaccine of Alum Precipitated Autoclaved Leishmania 
major (Alum-Alm) Mixed with Bcg or Mycobacterium Vaccae. Trop Biomed. 2010 Apr;27(1):89-102. PubMed PMID: 20562818.

[113] Tripathi P, Gupta SK, Sinha S, Sundar S, Dube A, Naik S. Prophylactic Efficacy of High-Molecular-Weight Antigenic Fractions of a Recent Clinical Isolate of Leishmania donovani against Visceral Leishmaniasis. Scand J Immunol. 2008 Nov;68(5):492-501. PubMed PMID: 18803606.

[114] Trotta T, Fasanella A, Scaltrito D, Gradoni L, Mitolo V, Brandonisio O, et al. Comparison between Three Adjuvants for a Vaccine against Canine Leishmaniasis: In Vitro Evaluation of Macrophage Killing Ability. Comp Immunol Microbiol Infect Dis. 2010 Mar;33(2):175-182. PubMed PMID: 20061026.

[115] Poot J, Janssen LH, van Kasteren-Westerneng TJ, van der Heijden-Liefkens KH, Schijns VE, Heckeroth A. Vaccination of Dogs with Six Different Candidate Leishmaniasis Vaccines Composed of a Chimerical Recombinant Protein Containing Ribosomal and Histone Protein Epitopes in Combination with Different Adjuvants. Vaccine. 2009 Jul 16;27(33):4439-4446. PubMed PMID: 19500553.

[116] Heldwein KA, Liang MD, Andresen TK, Thomas KE, Marty AM, Cuesta N, et al. TLR2 and TLR4 Serve Distinct Roles in the Host Immune Response against Mycobacterium bovis BCG. J Leukoc Biol. 2003 Aug;74(2):277-286. PubMed PMID: 12885945.

[117] von Meyenn F, Schaefer M, Weighardt H, Bauer S, Kirschning CJ, Wagner H, et al. Toll-Like Receptor 9 Contributes to Recognition of Mycobacterium bovis Bacillus Calmette-Guerin by Flt3-Ligand Generated Dendritic Cells. Immunobiology. 2006;211(6-8):557-565. PubMed PMID: 16920494.

[118] Smrkovski LL, Larson CL. Effect of Treatment with BCG on the Course of Visceral Leishmaniasis in BALB/c Mice. Infect Immun. 1977 Apr;16(1):249-257. PubMed PMID: 873609. Pubmed Central PMCID: 421515.

[119] Weintraub J, Weinbaum FI. The Effect of BCG on Experimental Cutaneous Leishmaniasis in Mice. J Immunol. 1977 Jun;118(6):2288-2290. PubMed PMID: 864260.

[120] Modified Saponins Isolated from Quillaja saponaria - Us 5443829 A. Available from: https://www.google.com/patents/US5443829.

[121] Sun HX, Xie Y, Ye YP. Advances in Saponin-Based Adjuvants. Vaccine. 2009 Mar 13;27(12):1787-1796. PubMed PMID: 19208455.

[122] Kenney RT, Sacks DL, Sypek JP, Vilela L, Gam AA, Evans-Davis K. Protective Immunity Using Recombinant Human IL-12 and Alum as Adjuvants in a Primate Model of Cutaneous Leishmaniasis. J Immunol. 1999 Oct 15;163(8):4481-4488. PubMed PMID: 10510390.

[123] Nakanishi T, Hayashi A, Kunisawa J, Tsutsumi Y, Tanaka K, Yashiro-Ohtani Y, et al. Fusogenic Liposomes Efficiently Deliver Exogenous Antigen through the Cytoplasm into the MHC Class I Processing Pathway. Eur J Immunol. 2000 Jun;30(6):1740-1747. PubMed PMID: 10898512. 
[124] Pardakhty A, Shakibaie M, Daneshvar H, Khamesipour A, Mohammadi-Khorsand T, Forootanfar H. Preparation and Evaluation of Niosomes Containing Autoclaved Leishmania major: A Preliminary Study. J Microencapsul. 2012;29(3):219-224. PubMed PMID: 22150018.

[125] Dantas-Torres F. Leishmune Vaccine: The Newest Tool for Prevention and Control of Canine Visceral Leishmaniosis and Its Potential as a Transmission-Blocking Vaccine. Vet Parasitol. 2006 Oct 10;141(1-2):1-8. PubMed PMID: 16750885.

[126] Dodge F. Leishmune É Ética, É Legal E Protege. 2009. Available from: http:// www.leishmune.com.br/leishmaniose/Leishmune/Outros/Diversos/14682_folheto.pdf.

[127] Fernandes AP, Costa MM, Coelho EA, Michalick MS, de Freitas E, Melo MN, et al. Protective Immunity against Challenge with Leishmania (Leishmania) chagasi in Beagle Dogs Vaccinated with Recombinant A2 Protein. Vaccine. 2008 Oct 29;26(46): 5888-5895. PubMed PMID: 18786587.

[128] Virbac. Canileish ${ }^{\oplus}$ Veterinary Brochure - Portuguese Edition 2011 [cited 2013]. Available from: http://www.ruminal.com.ar/sites/default/files/vet\%20brochure.pdf.

[129] Moreno J, Vouldoukis I, Martin V, McGahie D, Cuisinier AM, Gueguen S. Use of a LiESP/QA-21 Vaccine (Canileish) Stimulates an Appropriate Th1-Dominated CellMediated Immune Response in Dogs. PLoS Negl Trop Dis. 2012;6(6):e1683. PubMed PMID: 22724031. Pubmed Central PMCID: 3378610.

[130] IDRI. First Vaccine against Fatal Visceral Leishmaniasis Enters Clinical Trial 2012. Available from: http://www.idri.org/press-2-22-12.php.

[131] clinicaltrials.gov. A Phase 1 Clinical Trial to Evaluate the Safety, Tolerability, and Immunogenicity of the Vaccine Candidates Leish-F3 + GLA-SE, Leish-F3 + MPL-SE, and Leish-F3 + SE in Healthy Adult Subjects 2013. Available from: http://clinicaltrials.gov/ct2/show/study/NCT01751048.

[132] IDRI. Idri and Zydus Sign Agreement for Development of Idri's Vaccine Candidate for Visceral Leishmaniasis (Kala-Azar) 2013. Available from: http://www.idri.org/ press-07-25-13.php.

[133] Tacchini-Cottier F, Weinkopff T, Launois P. Does T Helper Differentiation Correlate with Resistance or Susceptibility to Infection with L. major? Some Insights from the Murine Model. Front Immunol. 2012;3:32. PubMed PMID: 22566916. Pubmed Central PMCID: 3342012.

[134] Baptista-Fernandes T, Marques C, Roos Rodrigues O, Santos-Gomes GM. Intra-Specific Variability of Virulence in Leishmaniai infantum Zymodeme MON-1 Strains. Comp Immunol Microbiol Infect Dis. 2007 Jan;30(1):41-53. PubMed PMID: 17109961.

[135] Oliveira DM, Costa MA, Chavez-Fumagalli MA, Valadares DG, Duarte MC, Costa LE, et al. Evaluation of Parasitological and Immunological Parameters of Leishmania 
chagasi Infection in BALB/c Mice Using Different Doses and Routes of Inoculation of Parasites. Parasitol Res. 2012 Mar;110(3):1277-1285. PubMed PMID: 21915627.

[136] Cunha J, Carrillo E, Sanchez C, Cruz I, Moreno J, Cordeiro-da-Silva A. Characterization of the Biology and Infectivity of Leishmania infantum Viscerotropic and Dermotropic Strains Isolated from $\mathrm{HIV}^{+}$and HIV Patients in the Murine Model of Visceral Leishmaniasis. Parasites \& Vectors. 2013;6:122. PubMed PMID: 23622683. Pubmed Central PMCID: 3649922.

[137] Peters NC, Egen JG, Secundino N, Debrabant A, Kimblin N, Kamhawi S, et al. In Vivo Imaging Reveals an Essential Role for Neutrophils in Leishmaniasis Transmitted by Sand Flies. Science. 2008 Aug 15;321(5891):970-974. PubMed PMID: 18703742. Pubmed Central PMCID: 2606057.

[138] Thalhofer CJ, Chen Y, Sudan B, Love-Homan L, Wilson ME. Leukocytes Infiltrate the Skin and Draining Lymph Nodes in Response to the Protozoan Leishmania infantum chagasi. Infect Immun. 2011 Jan;79(1):108-117. PubMed PMID: 20937764. Pubmed Central PMCID: 3019875.

[139] Yurdakul P, Dalton J, Beattie L, Brown N, Erguven S, Maroof A, et al. CompartmentSpecific Remodeling of Splenic Micro-Architecture During Experimental Visceral Leishmaniasis. Am J Pathol. 2011 Jul;179(1):23-29. PubMed PMID: 21703391. Pubmed Central PMCID: 3123882.

[140] Smelt SC, Cotterell SE, Engwerda CR, Kaye PM. B Cell-Deficient Mice Are Highly Resistant to Leishmania donovani Infection, but Develop Neutrophil-Mediated Tissue Pathology. J Immunol. 2000 Apr 1;164(7):3681-3688. PubMed PMID: 10725726.

[141] Tacchini-Cottier F, Zweifel C, Belkaid Y, Mukankundiye C, Vasei M, Launois P, et al. An Immunomodulatory Function for Neutrophils During the Induction of a CD4 Th2 Response in BALB/c Mice Infected with Leishmania major. J Immunol. 2000 Sep 1;165(5):2628-2636. PubMed PMID: 10946291.

[142] Souto FO, Alves-Filho JC, Turato WM, Auxiliadora-Martins M, Basile-Filho A, Cunha FQ. Essential Role of CCR2 in Neutrophil Tissue Infiltration and Multiple Organ Dysfunction in Sepsis. Am J Respir Crit Care Med. 2011 Jan 15;183(2):234-242. PubMed PMID: 20732989.

[143] Sato N, Ahuja SK, Quinones M, Kostecki V, Reddick RL, Melby PC, et al. CC Chemokine Receptor (CCR)2 Is Required for Langerhans Cell Migration and Localization of T Helper Cell Type 1 (Th1)-Inducing Dendritic Cells. Absence of CCR2 Shifts the Leishmania major-Resistant Phenotype to a Susceptible State Dominated by Th2 Cytokines, B Cell Outgrowth, and Sustained Neutrophilic Inflammation. J Exp Med. 2000 Jul 17;192(2):205-218. PubMed PMID: 10899907. Pubmed Central PMCID: 2193245.

[144] Conrad SM, Strauss-Ayali D, Field AE, Mack M, Mosser DM. Leishmania-Derived Murine Monocyte Chemoattractant Protein 1 Enhances the Recruitment of a Restrictive Population of CC Chemokine Receptor 2-Positive Macrophages. Infect Immun. 2007 Feb;75(2):653-665. PubMed PMID: 17088347. Pubmed Central PMCID: 1828528. 
[145] Meddeb-Garnaoui A, Zrelli H, Dellagi K. Effects of Tropism and Virulence of Leishmania Parasites on Cytokine Production by Infected Human Monocytes. Clin Exp Immunol. 2009 Feb;155(2):199-206. PubMed PMID: 19040614. Pubmed Central PMCID: 2675250

[146] Liu D, Uzonna JE. The P110 Delta Isoform of Phosphatidylinositol 3-Kinase Controls the Quality of Secondary Anti-Leishmania Immunity by Regulating Expansion and Effector Function of Memory T Cell Subsets. J Immunol. 2010 Mar 15;184(6):3098-3105. PubMed PMID: 20154209.

[147] Mueller SN, Gebhardt T, Carbone FR, Heath WR. Memory T Cell Subsets, Migration Patterns, and Tissue Residence. Annu Rev Immunol. 2012 Dec 3. PubMed PMID: 23215646 .

[148] Resende M, Moreira D, Augusto J, Cunha J, Neves B, Cruz MT, et al. Leishmania-Infected MHC Class I ${ }^{\text {high }}$ Dendritic Cells Polarize CD4 ${ }^{+}$T Cells toward a Nonprotective T-bet IFN-gamma ${ }^{+}$IL-10+ Phenotype. J Immunol. 2013 Jul 1;191(1):262-273. PubMed PMID: 23729437.

[149] Owens BM, Beattie L, Moore JW, Brown N, Mann JL, Dalton JE, et al. IL-10-Producing Th1 Cells and Disease Progression Are Regulated by Distinct CD11c(+) Cell Populations During Visceral Leishmaniasis. PLoS Pathog. 2012;8(7):e1002827. PubMed PMID: 22911108. Pubmed Central PMCID: 3406093.

[150] Anderson CF, Oukka M, Kuchroo VJ, Sacks D. CD4(+)CD25(-)Foxp3(-) Th1 Cells Are the Source of IL-10-Mediated Immune Suppression in Chronic Cutaneous Leishmaniasis. J Exp Med. 2007 Feb 19;204(2):285-297. PubMed PMID: 17283207. Pubmed Central PMCID: 2118728.

[151] Bogdan C, Moll H, Solbach W, Rollinghoff M. Tumor Necrosis Factor-alpha in Combination with Interferon-gamma, but Not with Interleukin 4 Activates Murine Macrophages for Elimination of Leishmania major Amastigotes. Eur J Immunol. 1990 May; 20(5):1131-1135. PubMed PMID: 2113475.

[152] Liew FY, Li Y, Millott S. Tumor Necrosis Factor-alpha Synergizes with IFN-gamma in Mediating Killing of Leishmania major through the Induction of Nitric Oxide. J Immunol. 1990 Dec 15;145(12):4306-4310. PubMed PMID: 2175327.

[153] Chan J, Xing Y, Magliozzo RS, Bloom BR. Killing of Virulent Mycobacterium tuberculosis by Reactive Nitrogen Intermediates Produced by Activated Murine Macrophages. J Exp Med. 1992 Apr 1;175(4):1111-1122. PubMed PMID: 1552282. Pubmed Central PMCID: 2119182.

[154] Darrah PA, Patel DT, De Luca PM, Lindsay RW, Davey DF, Flynn BJ, et al. Multifunctional Th1 Cells Define a Correlate of Vaccine-Mediated Protection against Leishmania major. Nat Med. 2007 Jul;13(7):843-850. PubMed PMID: 17558415. 
[155] Seder RA, Darrah PA, Roederer M. T-Cell Quality in Memory and Protection: Implications for Vaccine Design. Nat Rev Immunol. 2008 Apr;8(4):247-258. PubMed PMID: 18323851.

[156] Lichterfeld M, Yu XG, Waring MT, Mui SK, Johnston MN, Cohen D, et al. HIV-1-Specific Cytotoxicity Is Preferentially Mediated by a Subset of CD8(+) T Cells Producing Both Interferon-gamma and Tumor Necrosis Factor-alpha. Blood. 2004 Jul 15;104(2): 487-494. PubMed PMID: 15059848.

[157] Maia C, Seblova V, Sadlova J, Votypka J, Volf P. Experimental Transmission of Leishmania infantum by Two Major Vectors: A Comparison between a Viscerotropic and a Dermotropic Strain. PLoS Negl Trop Dis. 2011 Jun;5(6):e1181. PubMed PMID: 21695108. Pubmed Central PMCID: 3114756. 